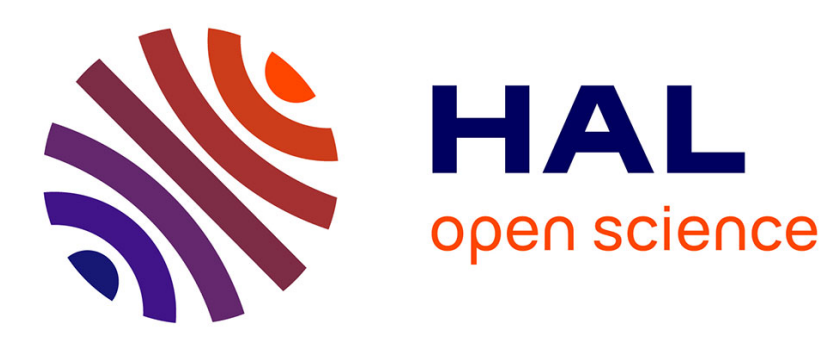

\title{
Late Wisconsinan grounding zones of the Laurentide Ice Sheet margin off the Québec North Shore (NW Gulf of St Lawrence)
}

\author{
P. Lajeunesse, Pierre Dietrich, J.-F Ghienne
}

\section{- To cite this version:}

P. Lajeunesse, Pierre Dietrich, J.-F Ghienne. Late Wisconsinan grounding zones of the Laurentide Ice Sheet margin off the Québec North Shore (NW Gulf of St Lawrence). Geological Society Special Publication, 2019, 475 (1), pp.241-259. 10.1144/SP475.10 . hal-02365034

\section{HAL Id: hal-02365034 \\ https://hal.science/hal-02365034}

Submitted on 15 Nov 2019

HAL is a multi-disciplinary open access archive for the deposit and dissemination of scientific research documents, whether they are published or not. The documents may come from teaching and research institutions in France or abroad, or from public or private research centers.
L'archive ouverte pluridisciplinaire HAL, est destinée au dépôt et à la diffusion de documents scientifiques de niveau recherche, publiés ou non, émanant des établissements d'enseignement et de recherche français ou étrangers, des laboratoires publics ou privés. 


\title{
Late Wisconsinan grounding zones of the Laurentide Ice Sheet margin off the Québec North Shore (NW Gulf of St Lawrence)
}

\author{
P. LAJEUNESSE ${ }^{1 *}$, P. DIETRICH ${ }^{2} \&$ J.-F. GHIENNE ${ }^{3}$ \\ ${ }^{1}$ Département de géographie, Université Laval, Québec City, Québec, Canada \\ ${ }^{2}$ Department of Geology, Auckland Park Kingsway Campus, University of \\ Johannesburg, Johannesburg, South Africa \\ ${ }^{3}$ Institut de Physique du Globe de Strasbourg, UMR 7516 CNRS/Université de \\ Strasbourg, Strasbourg, France \\ *Correspondence: patrick.lajeunesse@ggr.ulaval.ca
}

\begin{abstract}
Swath bathymetry data and seismic profiles collected in the NW Gulf of St Lawrence reveal a series of wedge-shaped depositional systems interpreted as grounding zone wedges (GZWs). Some segments of the GZWs change locally to form frontal moraines, or morainal banks, and subaqueous ice-contact fans, reflecting changes in either the nature of the ice margin or the rate of sediment input. These grounding zones (GZ) of the ice margin extend laterally along three isobaths at depths of 180 (GZ1), 120 (GZ2) and 80 (GZ3) m $( \pm 20 \mathrm{~m})$ along the Québec North Shore shelf, the 120 m-deep GZ2 system being traceable over a distance of $>300 \mathrm{~km}$. Associated GZWs can occur in three geometries along a same isobath system: curvilinear, lobate and shelf-break. GZ systems were built during three distinct stages of stabilization of the marine-based southeastern margin of the Laurentide Ice Sheet following its rapid retreat across the deeper waters of the Laurentian Channel in the Gulf of St Lawrence after $14.8 \mathrm{cal}$ ka BP. The occurrence of GZ along distinct isobaths indicates that bathymetry exerted a strong control on ice stabilization during deglaciation by reducing the relative water depth at the ice margin and thereby the buoyancy and rate of iceberg calving. However, fluctuations and readvances of the ice margin are also recorded by the overprinting of a portion of the GZ2 system by the younger GZ3 system, potentially suggesting an additional response to climate-driven forcing.
\end{abstract}

Ice-contact wedge-shaped deposits across glaciated shelves mark the former position of generally receding ice-sheet margins (e.g. Dowdeswell et al. 2016a). Among them, grounding-zone wedges (GZWs) are known to record phases of stepwise icesheet retreat on high-latitude continental margins (Dowdeswell et al. 2008) as they are deposited during episodic and temporary stillstands by significant accumulation of subglacial sediments at the grounding zone of fast-flowing ice-sheets (e.g. Mosola \& Anderson 2006; Dowdeswell \& Fugelli 2012; Batchelor \& Dowdeswell 2015; Dowdeswell et al. 2016a, b). GZWs have been interpreted as constructed under ice-shelf conditions, which restricted aggradation of subglacial sediments in favour of frontal progradation owing to low accommodation space under the ice, whereas moraines and ice-proximal fans are associated with tidewater ice margins (Batchelor \& Dowdeswell 2015). Some workers have proposed, however, that the construction of GZWs is controlled by subglacial sediment transport processes, whereby sediments prone to deformation are predisposed to build low-angle depositional landforms compared with stiffer sediments that generally build higher-angle landforms (Powell \& Alley 1997).

Ice-contact wedge-shaped deposits were first identified and mapped in the northwestern Gulf of St Lawrence by Syvitski \& Praeg (1989) using sparsely distributed airgun seismic data. Related sediment bodies, 20-40 m thick, were observed to form two major systems that extended laterally along two parallel isobaths over a distance of $<120 \mathrm{~km}$. These deposits were initially interpreted as ice-contact fans or frontal-dump moraines (Syvitski \& Praeg 1989) and/or as till aprons (Hein et al. 1993) constructed during temporary stabilization of the northward retreating ice margin across the Gulf of St Lawrence. Using swath bathymetry and seismostratigraphic data, these deposits were recently re-interpreted as GZWs by Lajeunesse (2016) based on (1) their wedge-shaped asymmetric geometry, (2) internal reflections indicative of sediment progradation and (3) their overall morphological similarity to sediment accumulations on other glaciated continental margins (e.g. Mosola \& Anderson 2006; Dowdeswell \& Fugelli 2012; Batchelor \& Dowdeswell 2015; Dowdeswell et al. 2016a). 


\section{P. LAJEUNESSE ET AL.}

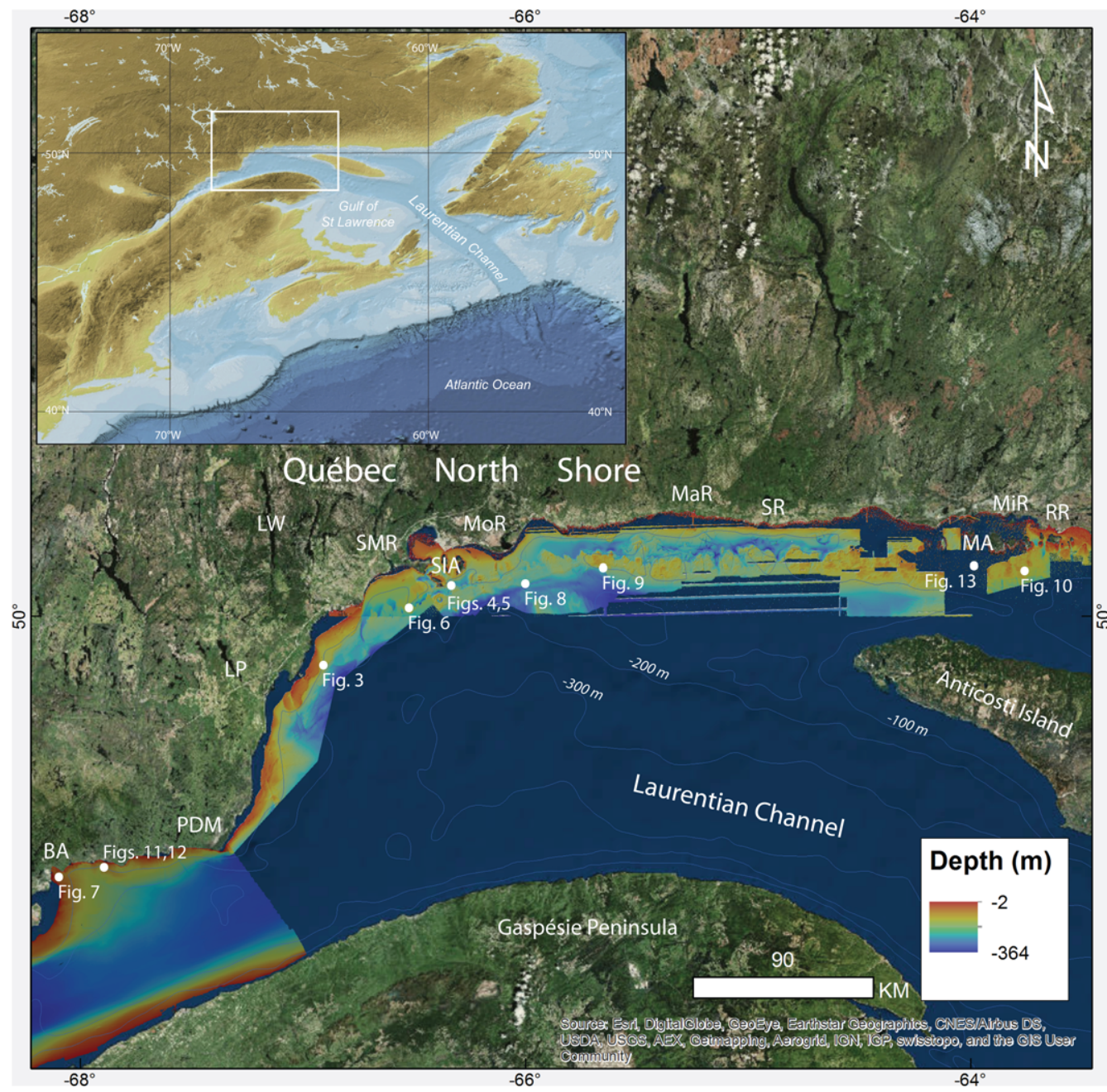

Fig. 1. Location map of the study area (inset map from GEBCO_08), off the Québec North Shore (eastern Canada), showing the coverage of the analysed swath bathymetry imagery and the location of Figures 3-13. BA,

Baie-des-Anglais; PDM, Pointe-des-Monts; LP, Lake Pentecôte; LW, Lake Walker; SMR, Ste Marguerite River; SIA, Sept-Îles Archipelago; MoR, Moisie Rivier; MaR, Manitou River; SR, Sheldrake River; MA, Mingan Archipelago; MiR, Mingan River; RR, Romaine River.

High-resolution (1-5 m) swath bathymetry data collected over recent decades along the Québec North Shore shelf (NW Gulf of St Lawrence, Eastern Canada; Fig. 1) by the Canadian Hydrographic Service, together with seismo-stratigraphic profiles, are here used to further detail and extend the regional mapping of GZWs and other submarine glacial depositional landforms first undertaken by Syvitski \& Praeg (1989), Hein et al. (1993) and Lajeunesse (2016). In this paper, we report and describe the geomorphology of GZWs, moraines and subaqueous ice-contact fans that have been recently mapped in great detail using swath bathymetry over a distance of $>300 \mathrm{~km}$ along the Québec North Shore. These glacial submarine landforms were constructed during the retreat of the marine-based southeastern margin of the Laurentide Ice Sheet following its rapid retreat in the deep waters of the Gulf of St Lawrence (Shaw et al. 2006).

\section{Physical setting and previous studies}

The Gulf of St Lawrence is a shallow (mean bathymetry $150 \mathrm{~m}$, Josenhans \& Lehman 1999) semienclosed sea bordering the eastern side of the Québec 


\section{LATE WISCONSINAN GROUNDING ZONES OF THE LAURENTIDE ICE SHEET MARGIN}

Province, exclusively lying on the continental platform. While open towards the Atlantic Ocean to the East, the Gulf of St Lawrence is supplied with water from the SW by the St Lawrence River and Estuary. The Gulf of St Lawrence is characterized by a prominent U-shaped cross-shelf trough, known as the Laurentian Channel, a deep (<550 m) and large submarine valley running from Tadoussac, at the mouth of the Saguenay Fjord, to the edge of the continental shelf south of Newfoundland (Todd 2016), over a distance of $>1000 \mathrm{~km}$ (Fig. 1). Towards its mouth, at the edge of the continental platform, the Laurentian Channel significantly shallows and leads to the Laurentian Fan, a trough mouth fan deposited over the continental slope (Piper et al. 2007). Towards the west, from the city of Sept-Îles (MoR) to Havre-St-Pierre (RR), a shallow shelf domain separates the Québec North Shore from the Laurentian Channel northern margin (Fig. 1). Mainly formed from slightly tilted and differentially eroded Paleozoic sedimentary rocks, it is characterized by a cuesta-like topography (Loring \& Nota 1973; Lajeunesse et al. 2013).

During the Last Glacial Maximum, dating back to c. $23 \mathrm{kyr}$ cal BP in Atlantic Canada, the margin of the Laurentide Ice Sheet (LIS) reached the edge of the continental shelf towards the east (Shaw et al. 2006). During this period, the Laurentian Channel is interpreted to have acted as a major conduit for ice flows draining the Québec-Labrador, Newfoundland and Appalachian ice domes of the LIS towards the mouth of the Laurentian Channel (Shaw et al. 2002, 2006; Margold et al. 2015; Stokes et al.

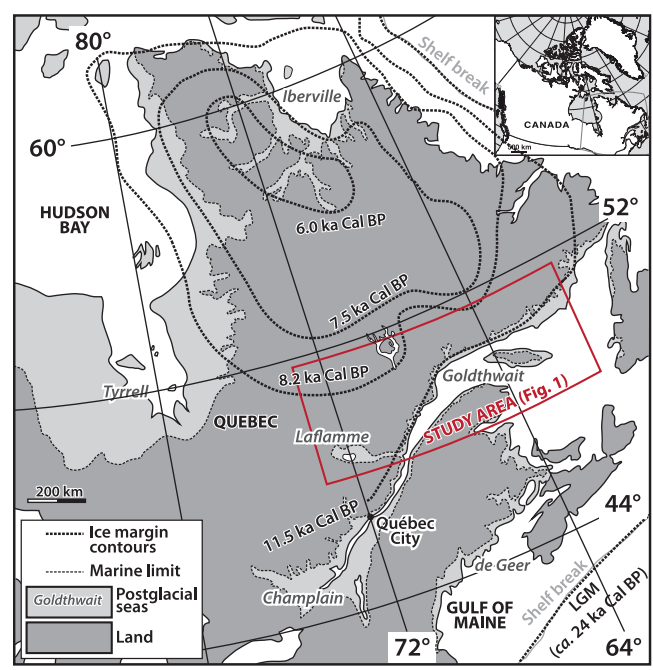

Fig. 2. Deglaciation pattern of the southeastern margin of the Laurentide Ice Sheet in Québec-Labrador, based on Occhietti et al. (2011).
2015). Deglaciation of the Gulf of St Lawrence area (Fig. 2) began about $16.8 \mathrm{kyr}$ cal BP with a rapid collapse of the ice occupying the Laurentian Channel and adjacent shelf areas leading to the formation of a vast calving bay with abundant iceberg release into the North Atlantic (Shaw et al. 2002, 2006; Dyke 2004). This collapse triggered the segmentation of the LIS into the Québec-Labrador Ice Sector (QLIS) to the north and the Appalachian Sector to the south (Occhietti et al. 2011). On the Québec North Shore, the QLIS margin retreated in a north-northwestward direction and constructed between 12.7 and $11.55 \mathrm{kyr}$ cal $\mathrm{BP}$ a series of small moraines found today on land in the Pointedes-Monts/Baie-Trinité area (Klassen et al. 1992; Fulton 1995; Occhietti et al. 2004; 2011). This area was probably the first to be deglaciated in the Québec North Shore area. Some of these moraines were correlated with the 13-11.5 kyr cal BP (Younger Dryas) St Narcisse moraine (Occhietti et al. 2004, 2011; Occhietti 2007) towards the east. The terrestrial Sept-Îles area was deglaciated prior to $10.8 \mathrm{kyr}$ cal BP, the oldest date found on-land in proximal glaciomarine deposits giving an age of $10840 \pm 50$ yr BP (Dietrich et al. 2018). According to the reconstruction of Occhietti et al. (2011) and in agreement with the aforementioned date, the deposition of the Lac Daigle moraine located 10-15 km inland NW of Sept-Îles is dated back to $c$. $10.8 \mathrm{kyr}$ cal BP. This moraine was deposited during a stabilization-re-advance phase associated with the transition from a marine- to a terrestrial-based ice margin. It built an ice-contact fan that progressively aggraded and prograded to form a sandur-delta (Dietrich et al. 2016). The Lac Daigle moraine corresponds to a segment of the larger-scale 11.2 10.8 kyr cal BP Québec North Shore moraine that extends for some $800 \mathrm{~km}$ between the Manicouagan River and Lake Melville (Dubois \& Dionne 1985; Klassen et al. 1992; Occhietti et al. 2004, 2011). Following the deposition of the Québec North Shore moraine, the LIS margin continued its retreat towards the NNW, leaving behind large systems of eskers and flutings (Boulton \& Clark 1990; Brennand 2000; Clark et al. 2000; Storrar et al. 2014). Although controversial, the final disappearance of the residual dome of the QLIS over northern Québec occurred at c. $5.5 \mathrm{kyr}$ cal BP (e.g. Occhietti et al. 2011; Clark et al. 2000; Storrar et al. 2014; Stokes et al. 2015; Margold et al. 2015).

The marine invasion (here referred to as the Goldthwait Sea) over glacio-isostatically flexured lowlands reached 130-150 $\mathrm{m}$ above sea-level in the study area (Fig. 2; Dredge 1983; Hein et al. 1993; Bernatchez \& Dubois 2004; Dietrich et al. 2016, 2018). Coeval and subsequent glacio-isostatic adjustment led to continuous relative sea-level (RSL) fall along the Québec North Shore, in spite of 


\section{P. LAJEUNESSE ET $A L$.}

concomitant global eustatic sea-level rise (Tarasov et al. 2012; Peltier et al. 2015) and permitted the partial emergence of the sedimentary sequence emplaced throughout deglaciation (Normandeau et al. 2017). Deglacial sedimentary sequences consist of glaciomarine, glaciofluvial deltaic then deltaic depositional environments (Loring \& Nota 1973; Syvitski \& Praeg 1989; Hein et al. 1993; Josenhans \& Lehman 1999; Normandeau et al. 2013, 2017). The resulting depositional architecture is described by Dietrich et al. (2018, see their Fig. 4).

Five seismo-stratigraphic units have been identified in the offshore of the study area (Syvitski \& Praeg 1989; Hein et al. 1993; Josenhans \& Lehman 1999; St-Onge et al. 2008; Normandeau et al. 2013, 2017; Todd 2016): ice-contact (Unit 1), ice-proximal glaciomarine (Unit 2), ice-distal glaciomarine (Unit 3), paraglacial deltaic (Unit 4) and postglacial (Unit 5). The ice-contact Unit 1 consists of diamictic material overlying bedrock and showing either incoherent or offlapping inner reflectors. In some sectors, bodies of this patchy unit can reach 10$40 \mathrm{~m}$ in thickness and 500-2000 $\mathrm{m}$ in length along the seismic profiles. They show an asymmetric wedge-shaped, coast-parallel geometry typical of grounding zone (GZ) depositional systems (Syvitski 1991; Dowdeswell \& Fugelli 2012). Two early ice stillstands were identified offshore Sept-Îles from the presence of these thick ice-contact wedge-shaped deposits, down to $180 \mathrm{~m}$ b.s.l., the longest of which can be followed over $120 \mathrm{~km}$ (Hein et al. 1993; Syvitski 1993; Lajeunesse \& St-Onge 2013; Lajeunesse 2016). Lajeunesse (2016) described three wedge-shaped sediment bodies forming the grounding line depositional systems, some segments of which were interpreted as GZWs. Ice-proximal sediments (Unit 2) were rapidly deposited by meltwater discharge at or close to the terminus of the ice sheet (St-Onge et al. 2008). These predominantly silty sediments bearing ice-rafted debris show high-intensity, closely spaced and well-defined reflectors. Unit 2 rarely exceeds $10 \mathrm{~m}$ in thickness and conformably drapes bedrock or underlying ice-contact Unit 1. In some cases, Unit 2 sediments form wedge-shaped deposits that interfinger with Unit $1 \mathrm{GZ}$ deposits. Unit 3 consists of deep-water mud deposited at a relative distance from the ice margin by turbid meltwater plumes (Syvitski \& Praeg 1989; Duchesne et al. 2010). This unit is characterized by acoustically weakly stratified and continuous inner reflectors that conformably drape the underlying topography and can reach $>40 \mathrm{~m}$ thick. The virtual absence of ice-rafted debris in this unit as well as its timing of deposition indicate that it represents a prodeltaic system constructed along the Québec North Shore and fed by the rapidly ablating terrestrial QLIS (Normandeau et al. 2017). Paraglacial deltaic sediments (Unit 4), consisting predominantly of sand and silt, may reach $100 \mathrm{~m}$ in thickness immediately offshore of Sept-îles. On acoustic profiles, this unit shows closely spaced high-intensity inner reflectors with a ponded geometry and often exhibits buried channels and mass-movement deposits (Hein et al. 1993). Unit 4 records the ongoing glaciogenic-fed deltaic progradation over the shelf that delivered large siltand sand-sized sediments to the deep realm of the St Lawrence, down to the Laurentian Channel (Normandeau et al. 2017; Dietrich et al. 2017, 2018). Acoustically, Unit 5, consisting of mud and occasional sand facies, shows transparent and lowintensity inner reflectors with an onlap basin-fill geometry. Following the melting of the QLIS out of the drainage basins that led to an abrupt drop in sediment supply (Dietrich et al. 2018), postglacial sediments (Unit 5) were deposited under a decreasing rate of falling RSL and the installation of modern oceanographic and terrestrial conditions (Hein et al. 1993, Normandeau et al. 2013; Dietrich et al. 2018).

\section{Methods}

A hull-mounted Kongsberg-Simrad EM-1000 multibeam sonar operating at a frequency of $95 \mathrm{kHz}$ was used by the Canadian Hydrographic Service on the CCGS F.G. Creed to acquire a high-resolution bathymetric grid in the region between 1997 and 2011 (Fig. 1). Each pixel composing the bathymetric grid is about $c .5 \mathrm{~m}^{2}$ and depth resolution is $<0.5 \mathrm{~m}$ at $100 \mathrm{~m}$ water depth. The multibeam bathymetry was interpreted using the QPS Fledermaus ${ }^{\circledR}$ software. Maps were produced using the ArcGIS 10.5 software $^{\circledR}$. In addition, high-resolution sub-bottom profiles were acquired onboard the Coriolis II in 2005, 2006 and 2012, using a hull-mounted EdgeTech $\mathrm{X}-\mathrm{Star} 2.1$ sonar-Chirp system $(2-20 \mathrm{kHz})$. These data were visualised using the NRCan SegyJp $2^{\circledR}$ software. Airgun seismic data were collected by the Geological Survey of Canada (GSC) (Source: Natural Resources of Canada Marine Data Holding; Courtney 2013).

\section{Results}

On the Québec North Shore shelf, between Baiedes-Anglais and the Mingan Islands (Fig. 1), the swath bathymetry imagery combined with highresolution seismic profiles reveal wedge-shaped deposits that have been previously interpreted as GWZs on the basis of their geometry (low-angle surface up-ice and high-gradient front down-ice), internal architecture (clinoforms) and step-like surface morphology (Lajeunesse 2016; Figs 3-13). Our expanded dataset shows that these GZWs, together with newly recognized ones that locally laterally connect to morainal banks and subaqueous icecontact fans belong to three distinct GZ systems 
(a)

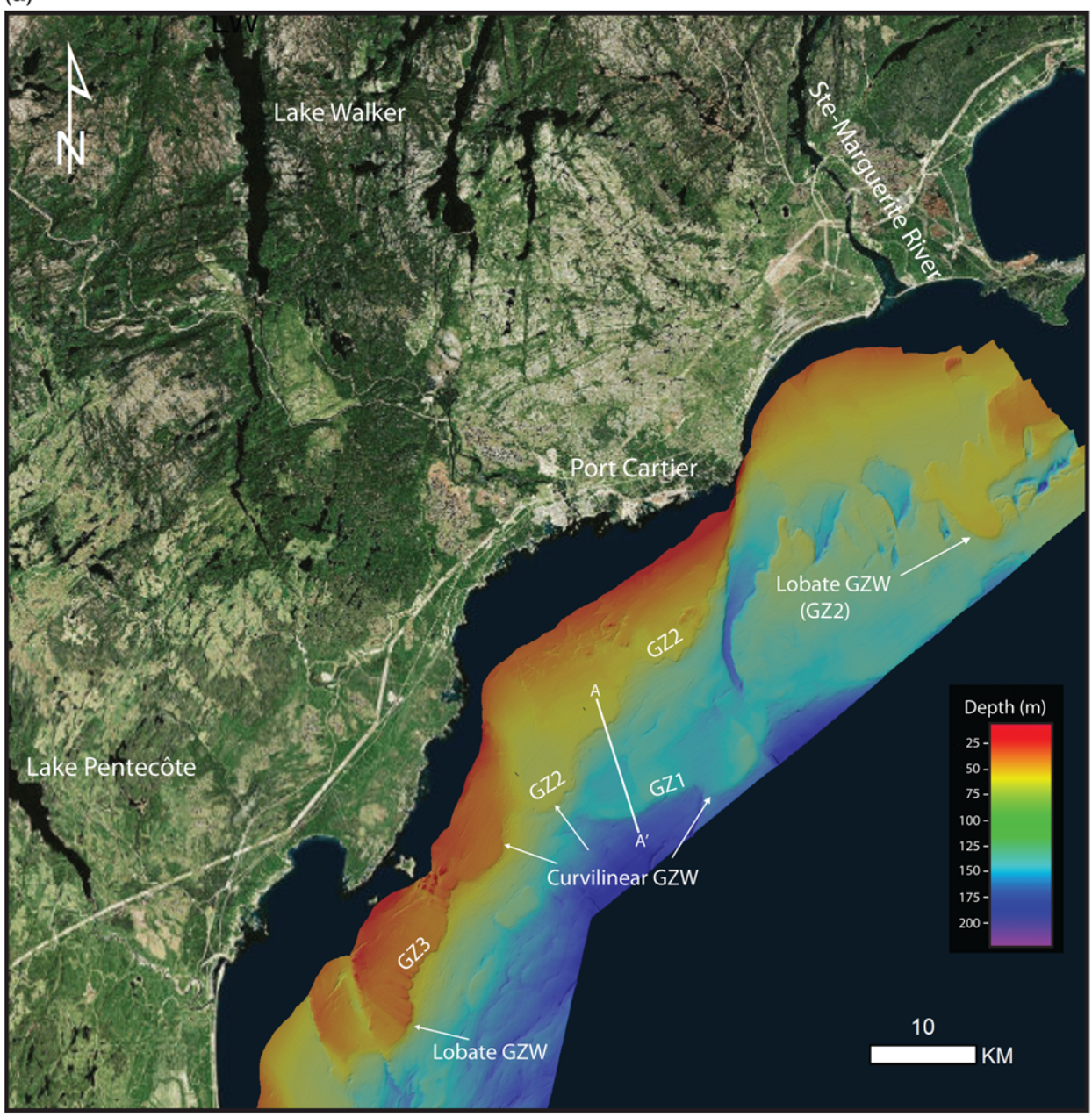

(b)

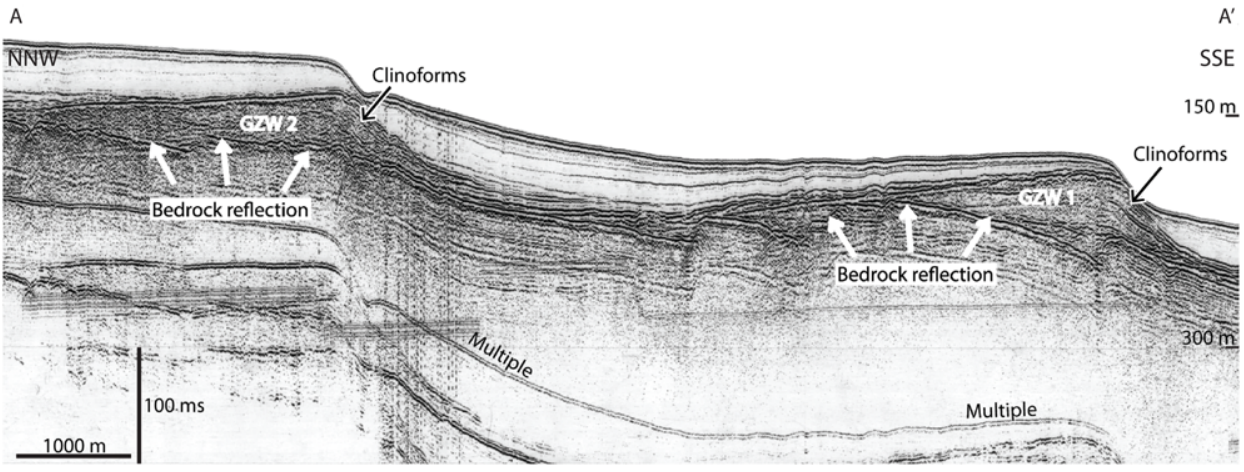

Fig. 3. (a) Swath bathymetry imagery of the three main GZ systems (GZ1, GZ2, GZ3) in the western sector of the study area, offshore the Pentecôte River (PR) mouth and Lake Walker valley (LW). Curvilinear and lobate GZWs are present in the smooth and gentle slopes of this sector. GZ1-GZ3 systems are identified on the map. (b) Airgun seismic profile (location A-A') across two curvilinear and backstepping GZWs at two different depths (GZ1 and GZ2). Depth based on TWTT at $1500 \mathrm{~m} \mathrm{~s}^{-1}$. Source: Natural Resources of Canada Marine Data Holding. 


\section{P. LAJEUNESSE ET AL.}

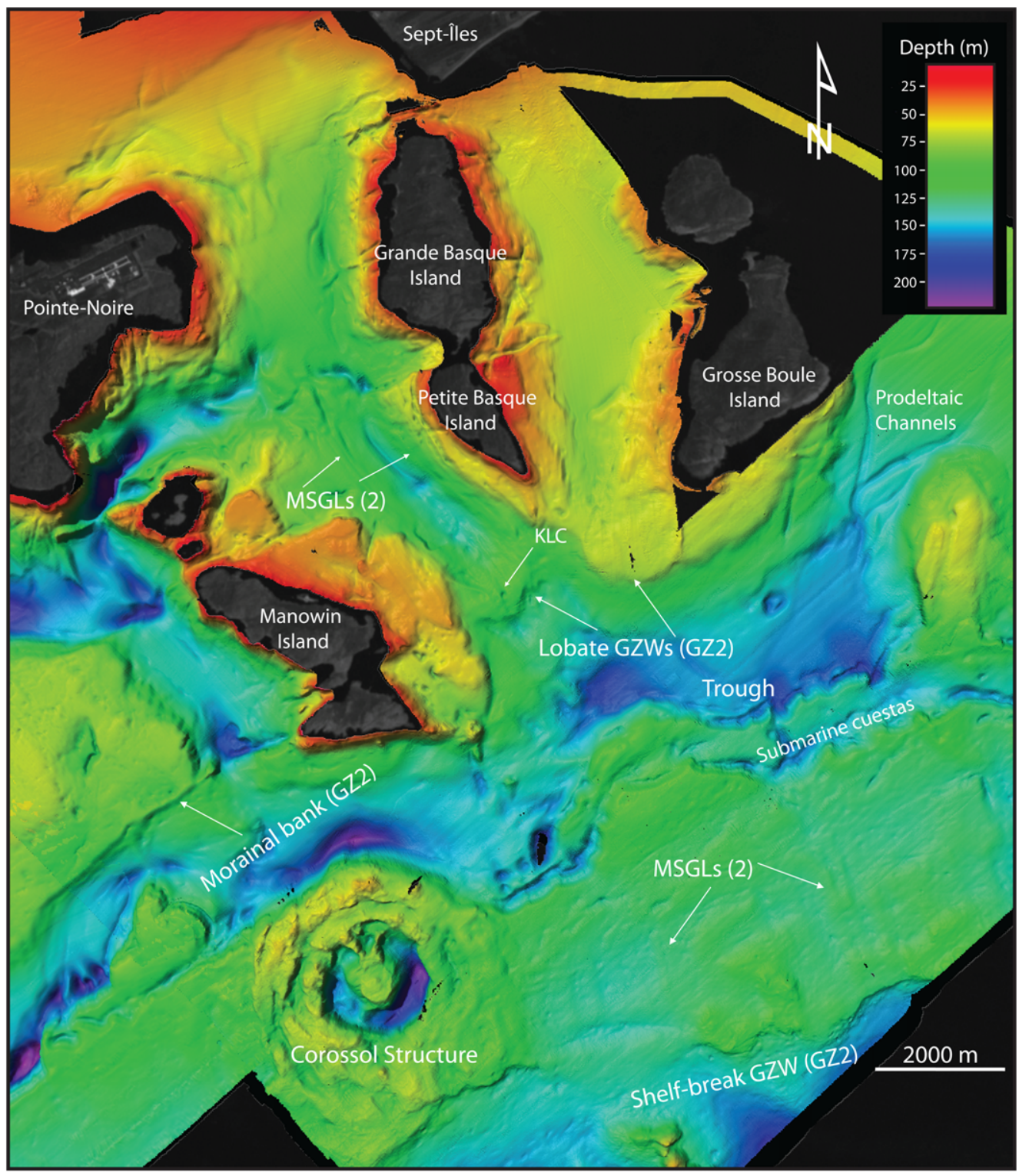

Fig. 4. Swath bathymetry imagery off the Moisie River mouth showing lobate and shelf-break GZWs, a morainal bank, kettle-like cavities (KLC) and MSGLs (MSGL system 2) up-ice (to the north). Channels on the Moisie delta slopes are probably responsible for delivery of recent sediments to the deeper areas of the sector. GZ2 is identified on the map.

that extend laterally along the same isobaths on the shelf and its bordering slopes. These GZ systems extend more or less in subparallel to each other within a distance of $<20$ from the coastline at depths of $180 \pm 20 \mathrm{~m}(\mathrm{GZ1}), 120 \pm 20 \mathrm{~m}(\mathrm{GZ2})$ and $80 \pm$ $20 \mathrm{~m}$ (GZ3). The swath bathymetry data also allowed the mapping of a series of De Geer moraines and mega-scale glacial lineations (MSGL) associated with these GZ systems. The geomorphology and distribution of these submarine glacial depositional landforms is described are the following sections.

\section{Grounding zone wedges}

On the seismic profiles collected by the GSC, GZWs consist of 20-40 m-thick depositional bodies 


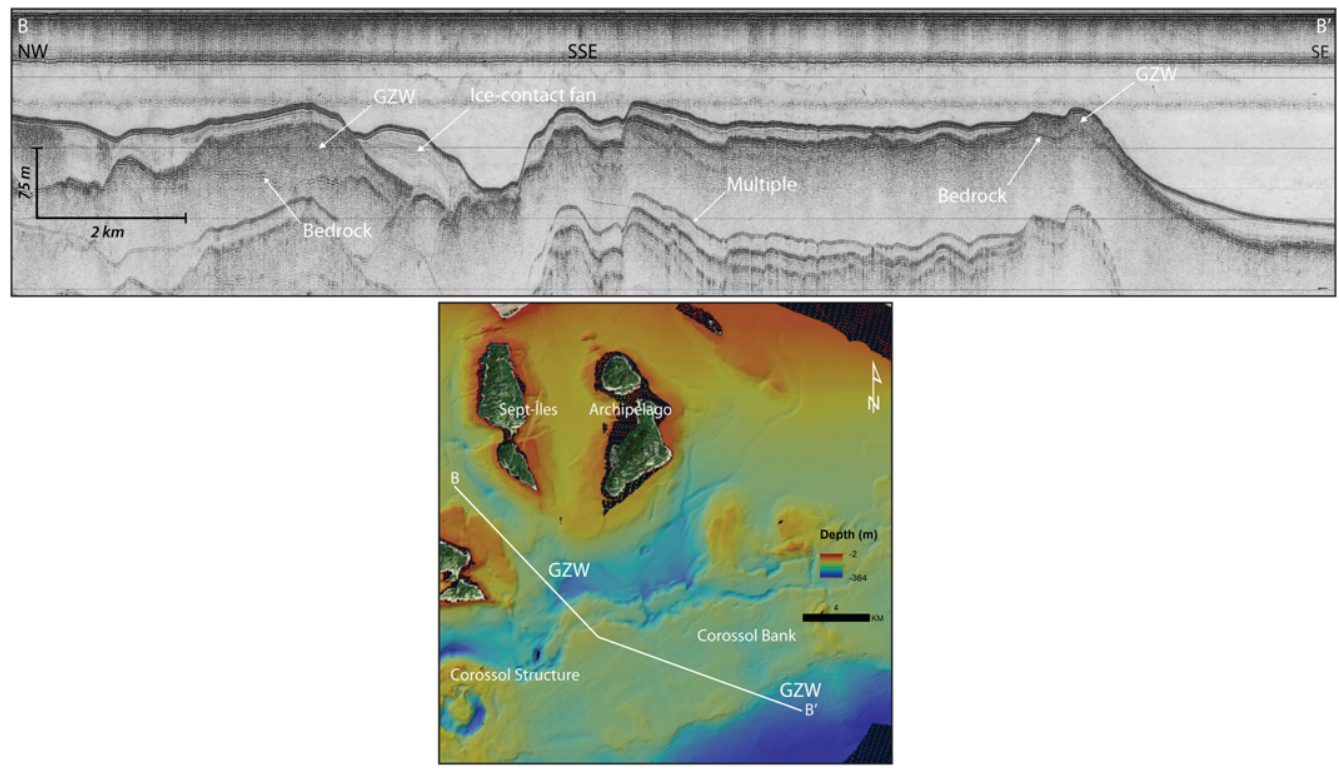

Fig. 5. Airgun seismic profile (location $B-B^{\prime}$ ) showing two GZW at the same depth. An ice-contact fan observed above the northern GZW indicates that a tidewater ice-margin reached a stillstand in this sector after the deposition of the GZW. The profile is located on the swath bathymetry map. Depth based on TWTT at $1500 \mathrm{~m} \mathrm{~s}^{-1}$. Source: Natural Resources of Canada Marine Data Holding.

characterized by chaotic internal reflections and series of dipping and offlapping reflections, forming clinoforms associated with progradation in front of the former ice margin. GZWs generally extend over a distance of 1200-3500 $\mathrm{m}$ along seismic profiles collected across them. They have an asymmetrical subsurface geometry, with a gentle slope up-ice (i.e. to the west, NW and north depending on their location along the shelf) and a steeper slope downice (i.e. to the east, SE and south). The steeper frontal slopes of the GZWs have angles of $4-6^{\circ}$; their northdipping lower angle upper surface slopes are generally $<0.4^{\circ}$.

Offshore Pentecôte River, a slight depression is present between two successive backstepping GZWs, forming gentle slopes grading offshore (Figs $1 \&$ 3). Such depressions are characterized by a thicker accumulation of paraglacial and postglacial sediments with a ponded geometry. The outer edge and frontal slope of some GZWs are occupied in some areas by 5-20 m-deep and 100-200 m-wide circular cavities (kettle-like cavities, KLC; Figs 4 $\& 6$ ) that have been interpreted as kettles (Lajeunesse 2016) formed above buried dead-ice bodies. Alternatively, these cavities could be interpreted as pockmarks or iceberg pits. The rising outer parts of the GZWs have a rather chaotic surface morphology owing to the presence of iceberg ploughmarks, whereas much smoother surface are imaged above the relatively thick draping of paraglacial and postglacial sediments in intervening depression. In some cases, the inner portion of a GZW is directly buried by the outer end of the younger GZW. For instance, offshore the Lake Walker valley and Pentecôte River mouth (Fig. 3a), the GZW associated with the GZ1 system is overstepped in places by a GZ2 GZW, which is in turn overstepped locally by a GZ3 GZW.

GZWs occur in three distinctive geometrical types: (1) curvilinear wedge; (2) lobate wedge; and (3) shelf-break wedge, each in well-defined physical settings. Curvilinear-type GZWs occur over gently dipping and smooth slopes on the shelf of the SW sector of the study area (Fig. 3), where the monoclinal Middle-Ordovician strata of the St Lawrence Platform gently dip towards the Laurentian Channel to form a series of cuestas (Loring \& Nota 1973; Lajeunesse et al. 2013). Curvilinear GZWs consist of low-angle sedimentary bodies draping the underlying bedrock that are bordered downslope by steeper frontal slopes that extend laterally along the same isobaths $( \pm 20 \mathrm{~m})$, forming 20-30 m-high steps on the seafloor. In some cases, the outer edge of curvilinear GZWs has a gently rising $\left(<0.6^{\circ}\right)$ slope (to the east and SE).

Lobate GZWs appear as prominent features along the GZ2 and GZ1 systems, forming tongue-shaped lobes (Figs 3a, 4, 5, 6 \& 7a). Lobate GZWs are especially observed along the offshore axis of the deeply 


\section{P. LAJEUNESSE ET $A L$.}

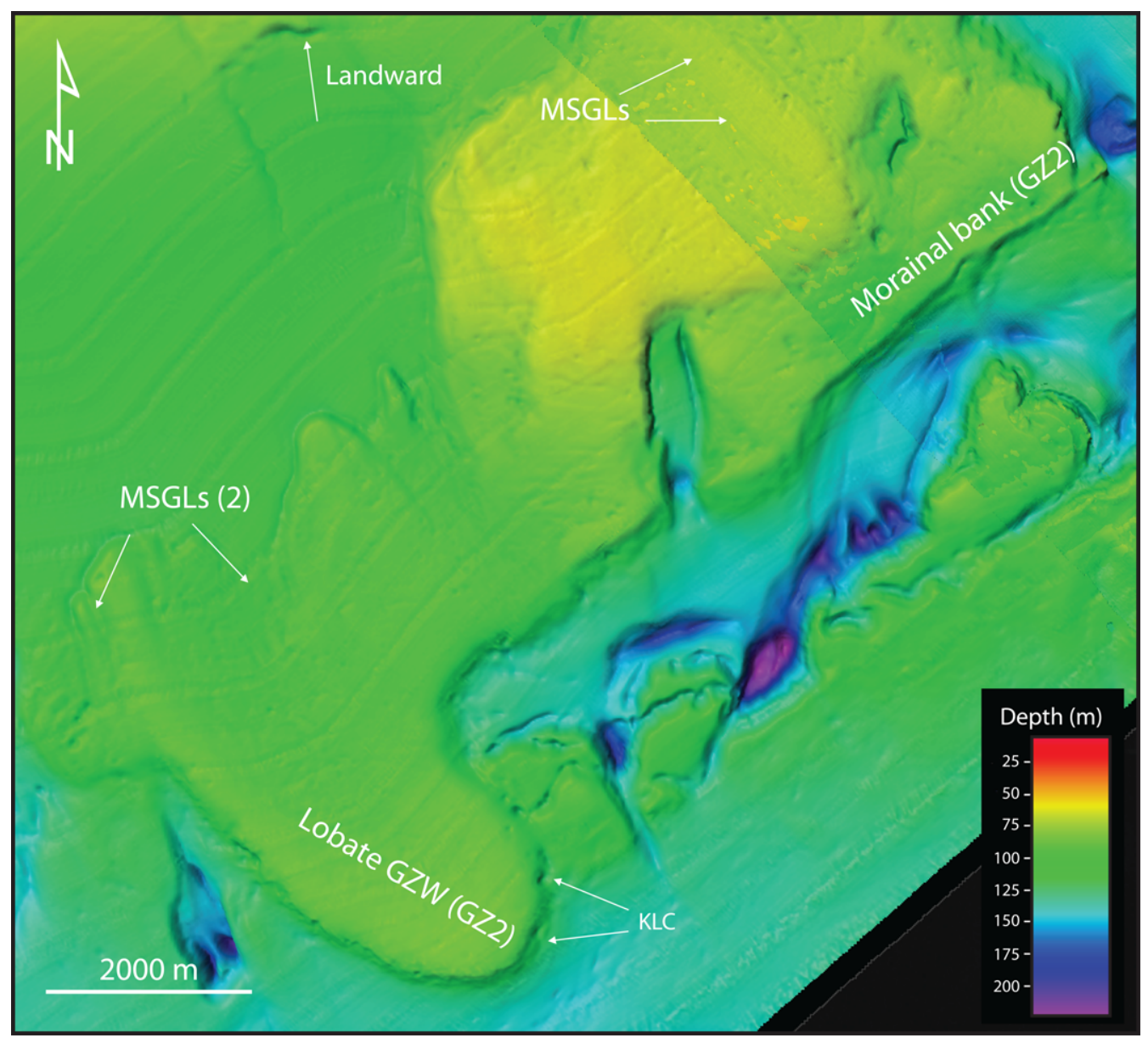

Fig. 6. Swath bathymetry imagery of a transition between a lobate GZW and a morainal bank offshore Ste Marguerite River. MSGLs (MSGL system 2) are observed up-ice of these two ice-contact deposits. KLCs are visible on the frontal slope of the GZW. GZ2 is identified on the map.

incised glacial valleys of lakes Walker and Pentecôte (Poiré et al. 2018), in association with the GZ2 and GZ3 systems, and of Ste Marguerite River, with the GZ2 system (Figs 3a \& 6). They are also observed in 'channels' between some islands of the Sept-Îles archipelago at depths of $c .120 \mathrm{~m}$, in association with the GZ2 system (Fig. 4), and in Baie-des-Anglais in association with the GZ3 system (Fig. 7a, b). Frontal slopes of lobate wedges are steeper and form a higher step ( $>40 \mathrm{~m}$ in height) than those of curvilinear wedges.

Shelf-break GZWs are observed in sectors where the morphology of the seafloor is marked by an abrupt break in slope (Figs 8-10). They occur on two particular shelf breaks extending in parallel with the coastline: (1) 10-20 km from the coastline, between the Moisie and Sheldrake river mouths at depths of c. $180 \mathrm{~m}$, within the GZ1 system (Fig. 8), and at c. $120 \mathrm{~m}$ within the GZ2 system (Fig. 9), at the edge of the gently-sloping cuesta shelf and on the upper slopes of the Laurentian Channel; and (2) $18-20 \mathrm{~km}$ from the coastline along a shallower shelf break offshore the Mingan River mouth at depths of c. $60 \mathrm{~m}$, within the GZ3 system (Fig. 10). Shelf-break GZWs form thick (20-40 m) depositional aprons deposited on the upper slopes whereas the updip shelf is overlain only by a thin (10$15 \mathrm{~m}$ ) sequence of glaciomarine and postglacial sediments. GZWs are not observed on the swath bathymetry imagery and seismic data north of these two sectors. However, several GSC seismic profiles reveal that they are present offshore to the west and SW of Anticosti Island along the northern slopes of the Laurentian Channel, at depths ranging from $c .60$ to $200 \mathrm{~m}$, and between the Mingan Islands and the Natashquan River mouth, at depths of $c$. 80- 
(a)

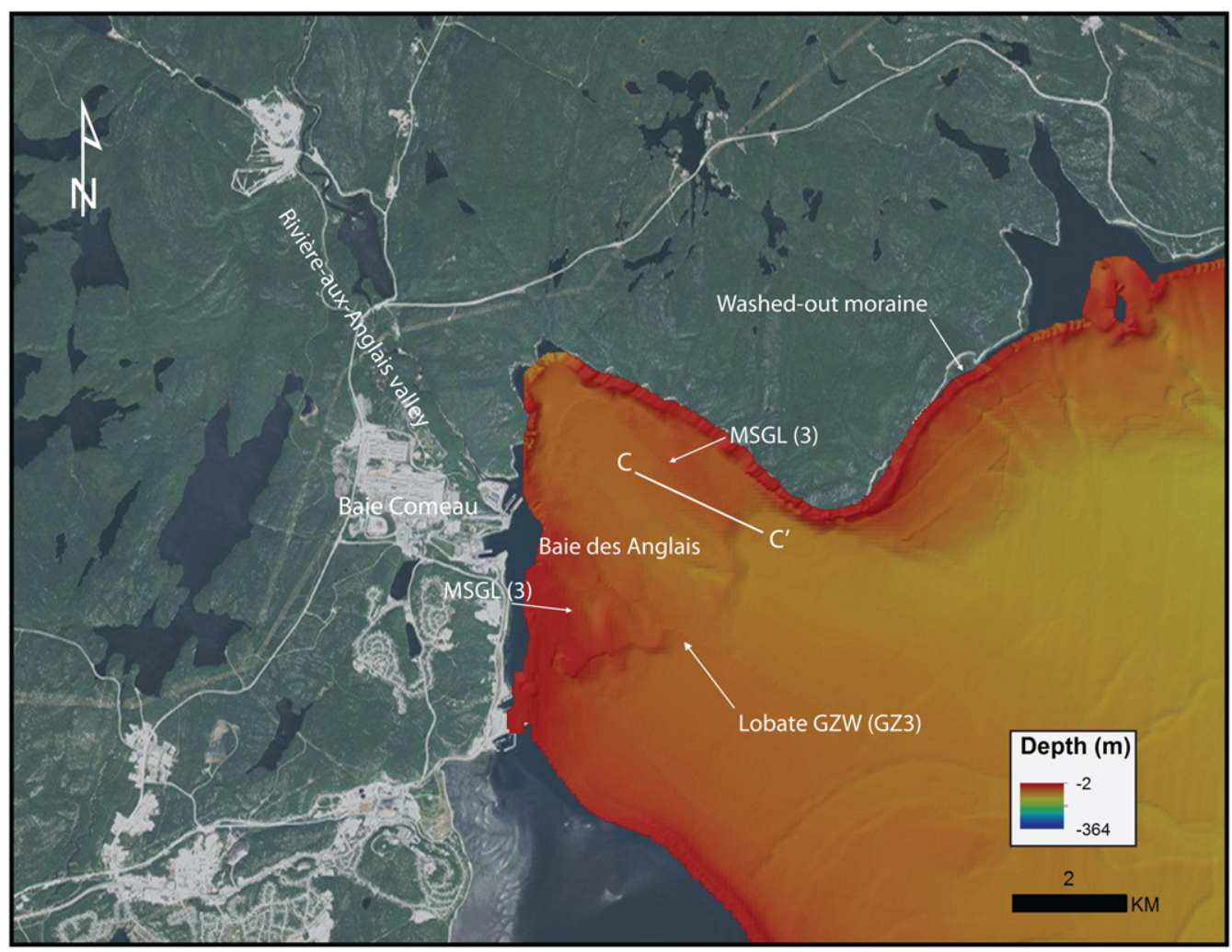

(b)

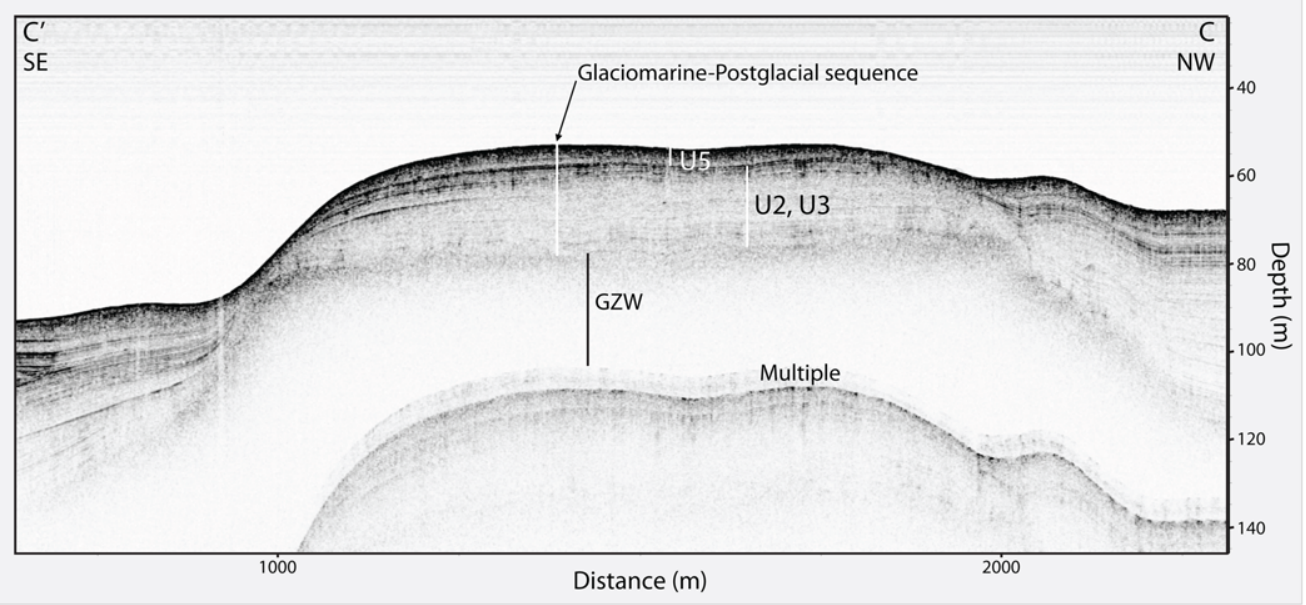

Fig. 7. (a) Swath bathymetry imagery of a lobate GZW in Baie-des-Anglais, at the western end of the study area. MSGLs (MSGL system 3) are present near the termini of this system. GZ3 is identified on the map. (b) Chirp sub-bottom profile (location C-C') of the GZW deposit covered by $>20 \mathrm{~m}$ of glaciomarine (U3) and postglacial sediments (U5). The paraglacial unit (U5) is not observed in this sector, as it occurs mostly offshore deltas. Depth based on TWTT at $1500 \mathrm{~m} \mathrm{~s}^{-1}$. 
(a)

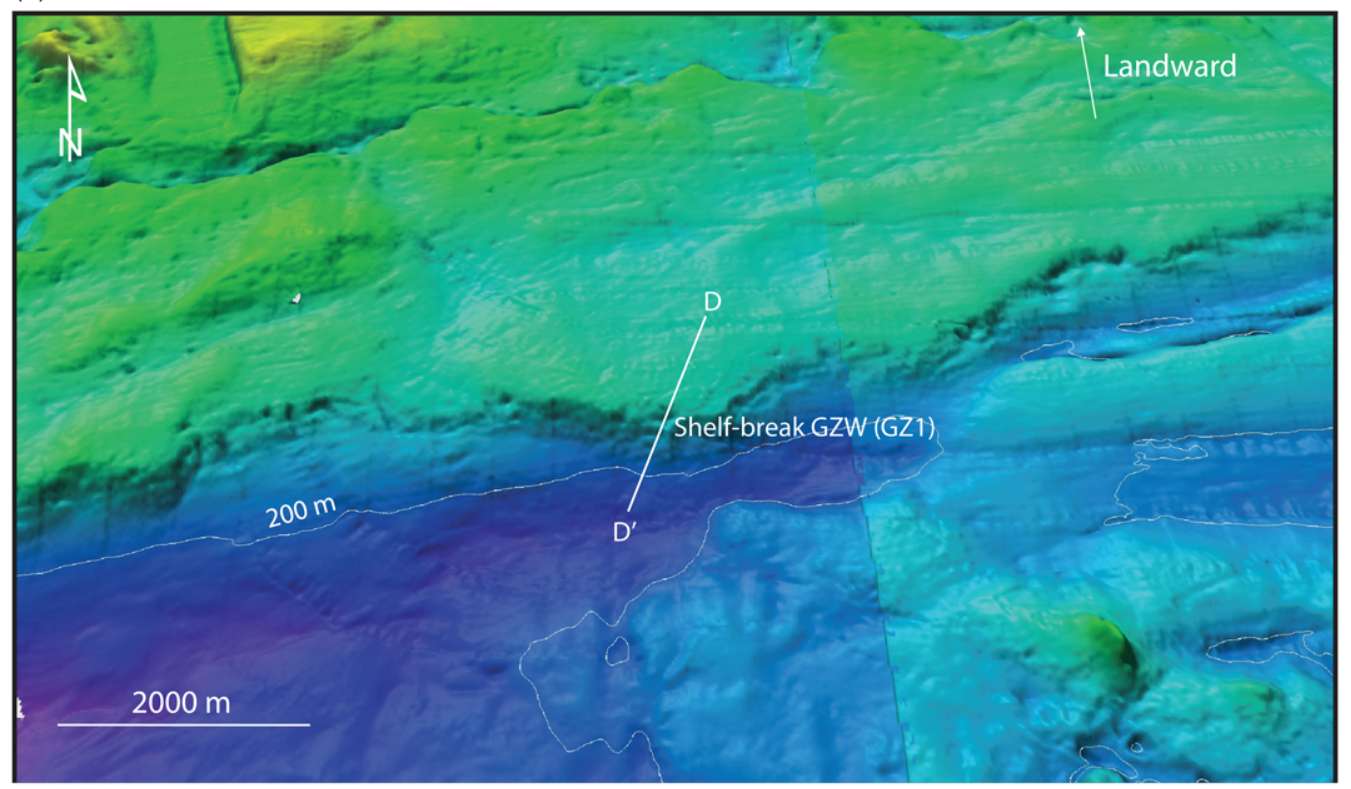

(b)

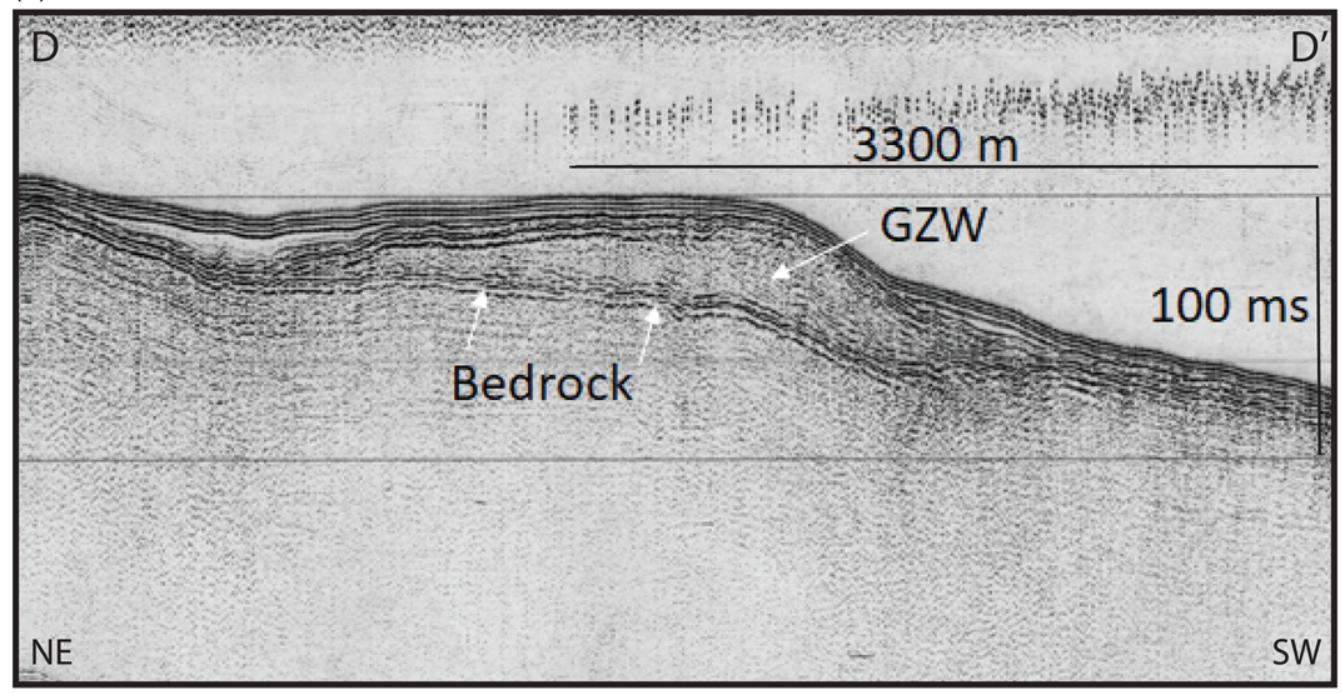

Fig. 8. (a) Swath bathymetry imagery of the shelf SE of Moisie River showing a major shelf escarpment on which shelf-break GZWs are observed on the airgun seismic data (b: D-D'; depth based on TWTT at $1500 \mathrm{~m} \mathrm{~s}^{-1}$ ). Source: Natural Resources of Canada Marine Data Holding. GZ1 is identified on the map (a).

100 m (Josenhans \& Lehman 1999). The lack of fullbottom swath bathymetry coverage in these sectors does not allow confirmation of their extension along definite isobaths.

In the SW sector of the study area, GZWs are not visible on the swath bathymetry imagery because the GZ3 system, which has been raised by glacio- isostatic rebound, continues either along the modern coastline or further onland, lying buried under more recent marine and coastal deposits. Segments of lobate GZWs are observed at low tide today off major valley axes, where they have been washed out and partially eroded by coastal and tidal currents, waves and sea ice (Figs $11 \& 12$ ). 
(a)

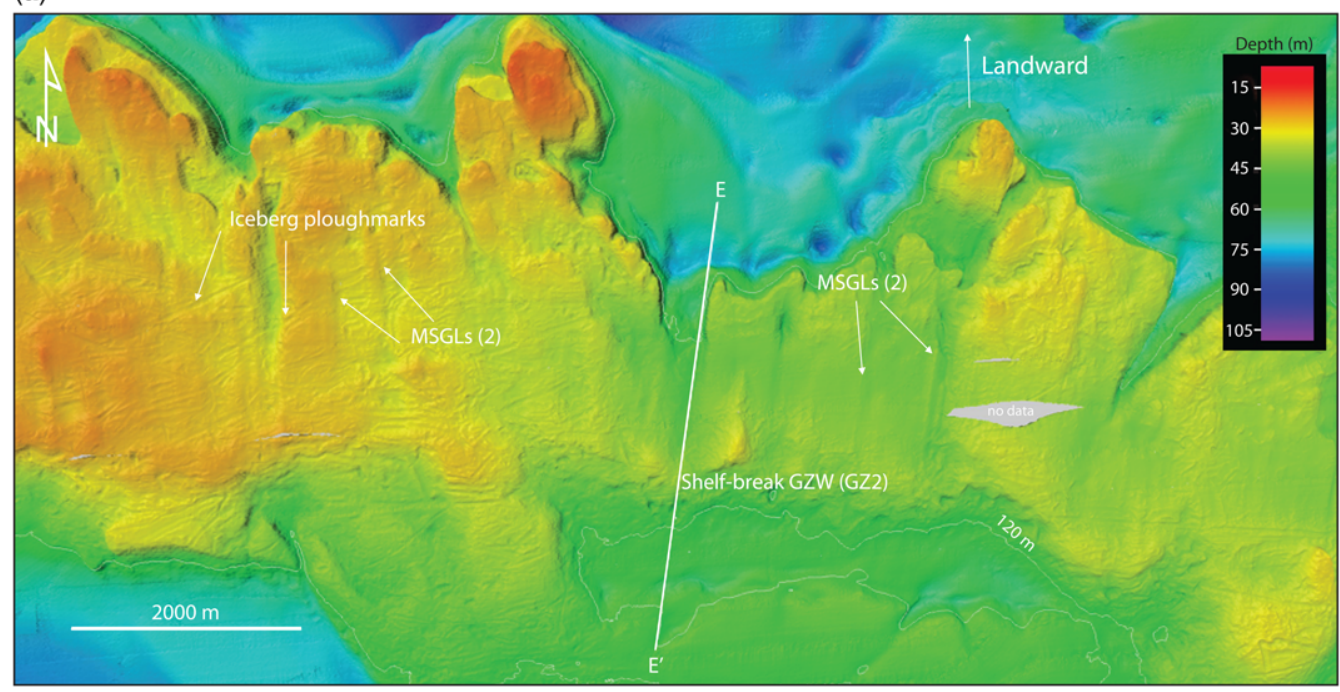

(b)

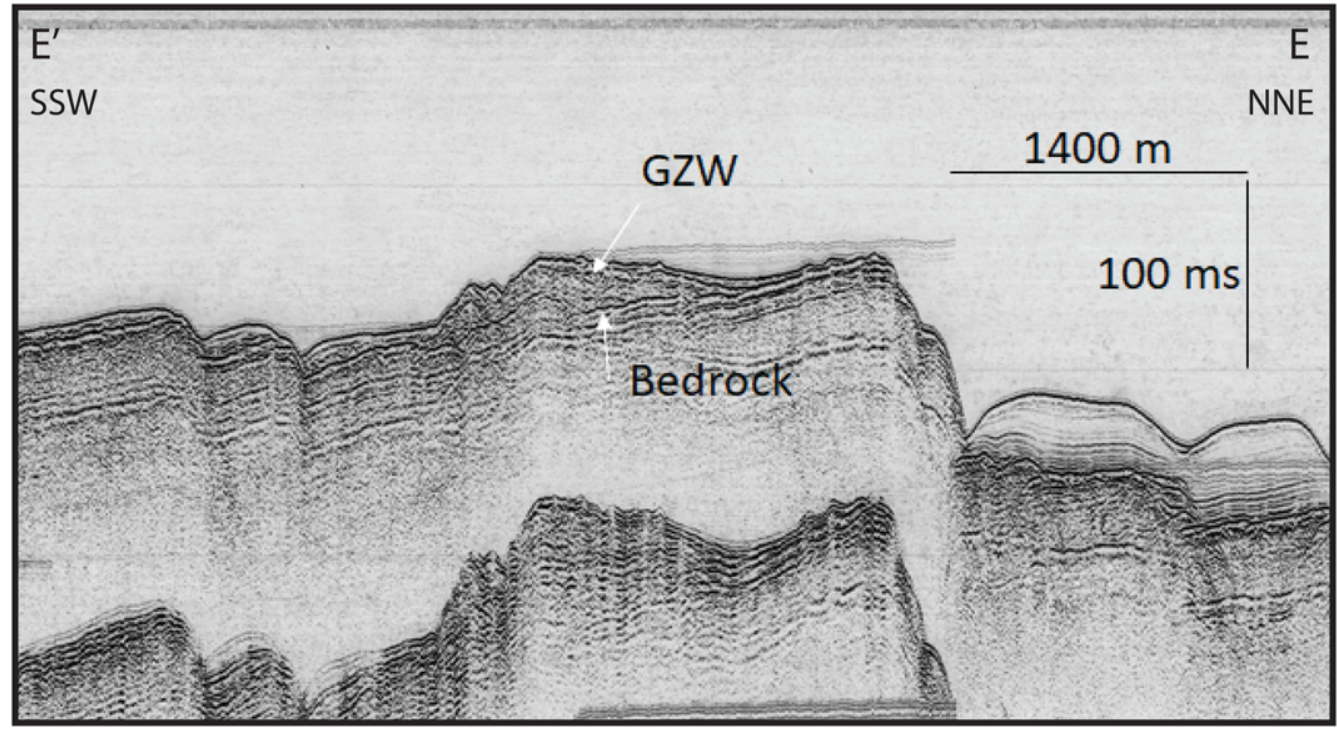

Fig. 9. (a) Swath bathymetry imagery of the shelf located halfway between the Moisie and Manitou river mouths showing iceberg ploughmarks and MSGLs (MSGL system 3) up-ice of the major escarpment where shelf-break GZWs (b: airgun seismic profile; location E-E'; depth based on TWTT at $1500 \mathrm{~m} \mathrm{~s}^{-1}$ ) were constructed. Source: Natural Resources of Canada Marine Data Holding. GZ2 is identified on the map (a).

Two GZWs occur at the same depths $(c .120 \mathrm{~m})$ south of the Sept-îles Archipelago (Figs 4 \& 5): a first south to the SE of the shelf-break (shelf-break type GZW) and a second to the NW at the southern end of the Sept-Îles Archipelago (lobate-type GZW). These two GZWs are part of the same system, as they are connected to each other immediately to the west of the Corossol structure along the $120 \mathrm{~m}$ isobath, suggesting that a subglacial basin existed in the trough located just north of the cuestas (Dietrich et al., 2018; their Fig. 6). This bedrock basin was probably eroded by the phase of preglacial fluvial erosion that formed the submarine cuestas of the St Lawrence Platform to the south (Loring \& 
(a)

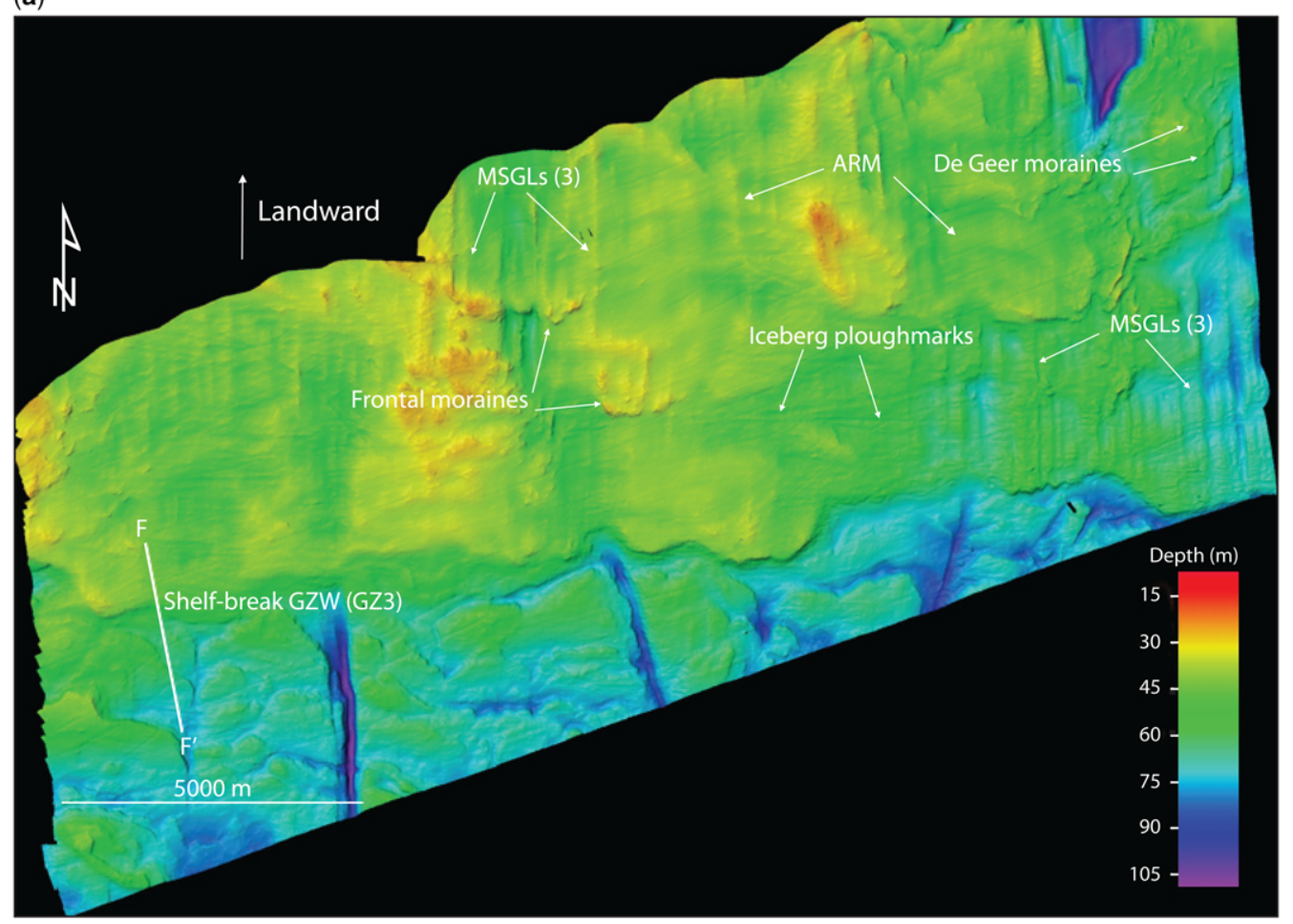

(b)

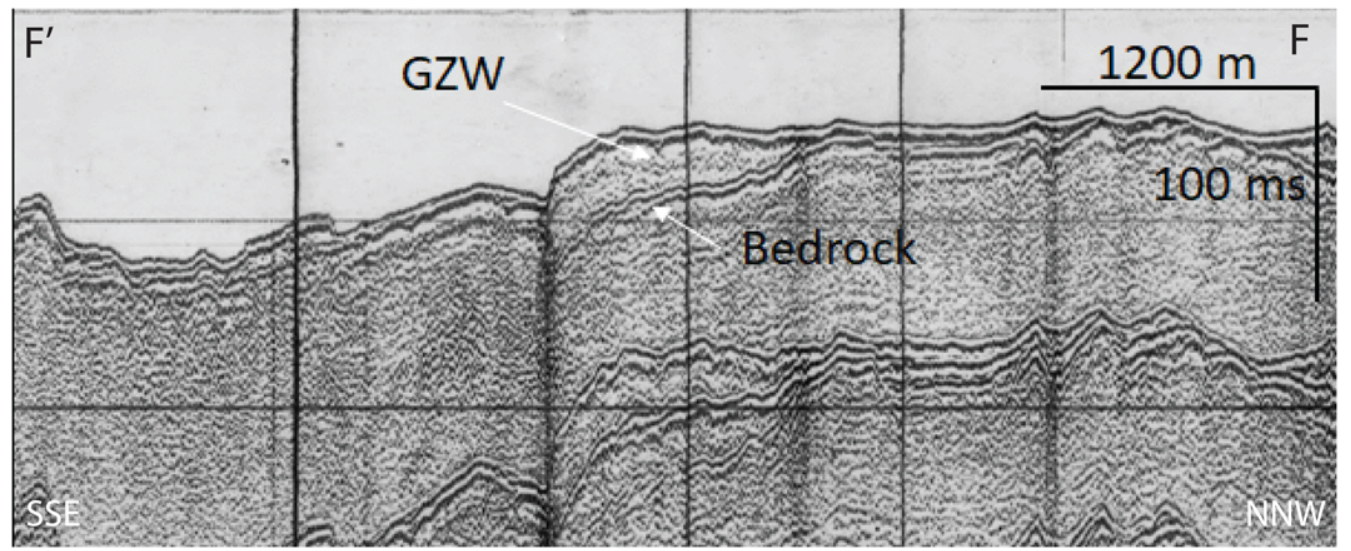

Fig. 10. (a) Swath bathymetry imagery of the shelf located south of the Mingan Archipelago where series of MSGLs, arcuate retreat moraine (ARM) and De Geer moraines occur up-ice of shelf-break GZWs (b: airgun seismic profile; location F-F'; depth based on TWTT at $1500 \mathrm{~m} \mathrm{~s}^{-1}$ ). Source: Natural Resources of Canada Marine Data Holding. GZ3 is identified on the map.

Nota 1973; Lajeunesse 2014), rather than by subglacial erosion. The trough is partly filled with a sequence of glaciomarine proximal (Unit 2) and distal (Unit 3), paraglacial deltaic (Unit 4) and postglacial sediments (Unit 5). A thick glaciomarine fan also observed on its NE flanks (Fig. 5) onlaps the GZW. Sediment gravity flows generated along the Moisie River delta slopes reach today this trench and form channels (Lajeunesse et al. 2007). Although the surface of these two GZWs are located at the same 


\section{LATE WISCONSINAN GROUNDING ZONES OF THE LAURENTIDE ICE SHEET MARGIN}

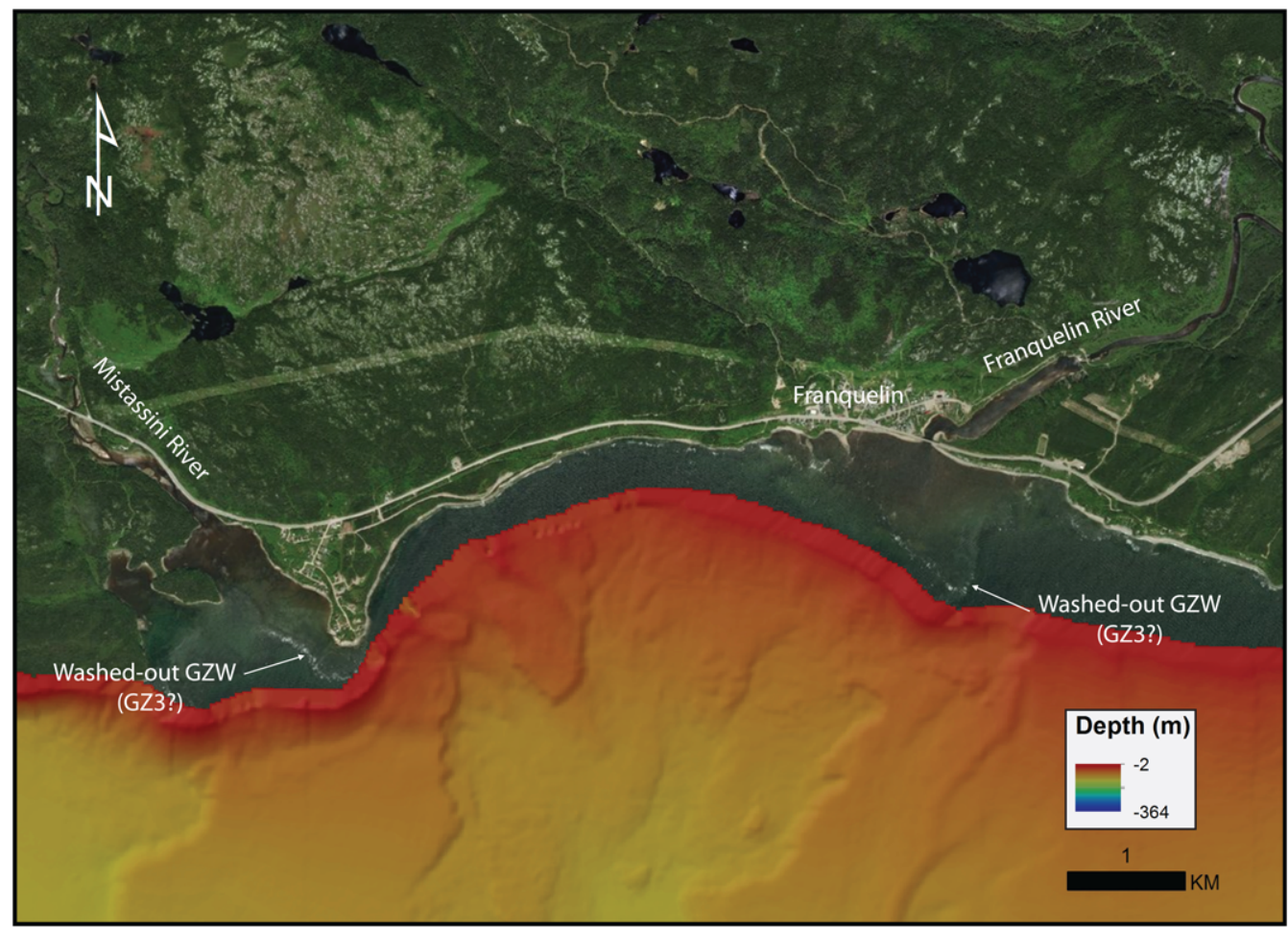

Fig. 11. Washed-out lobate coarse-grained deposits outcropping at low tide interpreted as GZWs observed along the coast near the town of Franquelin, in the eastern sector of the study area. These deposits now form boulders barricades. These deposits are possibly associated with GZ3, although no GZW or moraines have been observed in deeper waters (i.e. down-ice).

depths, bedrock is observed at a greater depth below the GZW to the NW than below the GZW to the SE.

\section{Morainal banks and other frontal moraines}

Morainal banks form 2-9 m-high ridges specifically related to the GZ2 system. On the swath bathymetry imagery, they are observed west of the Sept-Îles archipelago (Figs 4 \& 7) and SW of the Mingan Island, at depth of $c .120 \mathrm{~m}$. In this sector, the moraine forms an $11 \mathrm{~km}$-long ridge on a gently dipping $\left(<1^{\circ}\right)$ cuesta slope west of the shelf-break GZ2 system. Segments of moraines are also visible along the shoreline in some sectors, where they have been wave-winnowed to form boulder barricades in intertidal zones (Figs $11 \&$ 12). Series of smaller-scale recessional arc-shaped frontal moraines overprinting MSGLs are present at depths of $c .40 \mathrm{~m}$ on the shelf SE of the Mingan Island (Fig. 10a). In this sector, a series of seven distinct smaller-scale linear 1-2 mhigh frontal moraines are superimposed on the MSGLs with a spacing ranging between 150 and $250 \mathrm{~m}$. The regular geometry and spacing indicate that they are both De Geer moraines. Such submarine moraines are not observed in the central and eastern portion of the study area. Some segments of the Baie-Trinité moraine, which form in this area a portion of the Younger Dryas age St Narcisse moraine (Occhietti et al. 2011), are known to occur along the shoreline of the region as washed-out moraines (Bernatchez 2003), in the same manner as the lobate GZW described above.

\section{Subaqueous ice-contact fans}

Subaqueous ice-contact fans comprise a localized sequence of proximal to distal glaciomarine deposits (Unit 2) forming an apron by the delivery of sediments from glacial meltwaters during temporary stabilization of an ice margin (e.g. Lønne 1995; Lajeunesse \& Allard 2002). Such fans are observed at two sites on the Chirp sub-bottom data. At the southern end of the Sept-Îles Archipelago, between Manowin and Petite-Basque islands, a $<40 \mathrm{~m}$-thick ice-contact fan deposit is observed at a depth of $c$. $120 \mathrm{~m}$, just above a GZWs associated with the 


\section{P. LAJEUNESSE ET AL}

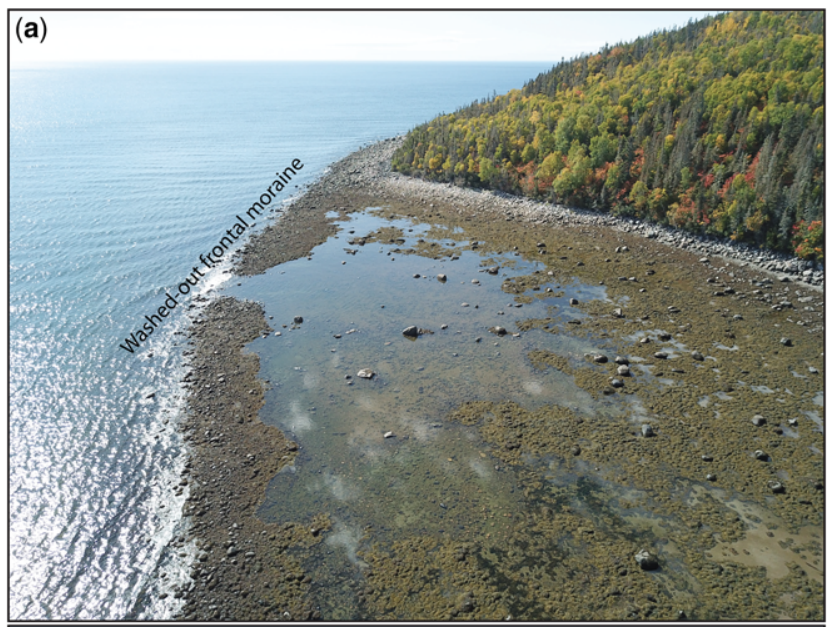

(b)

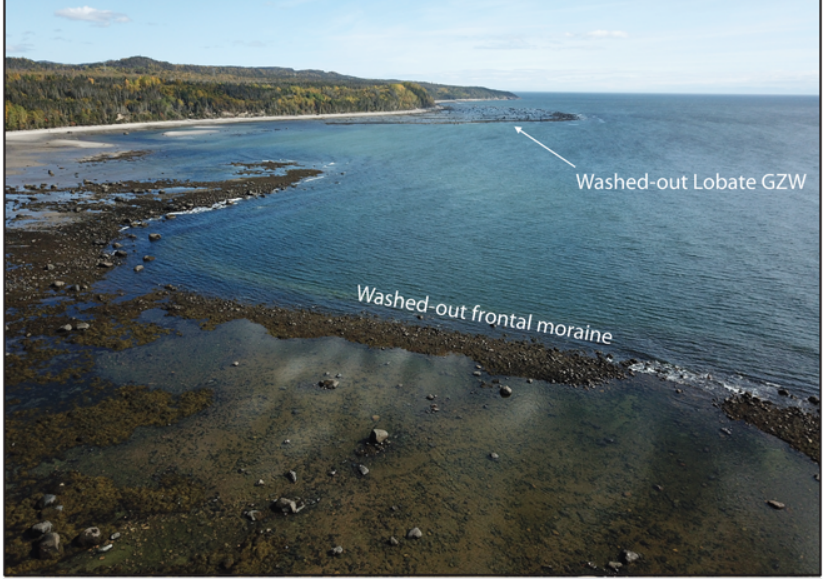

(c)

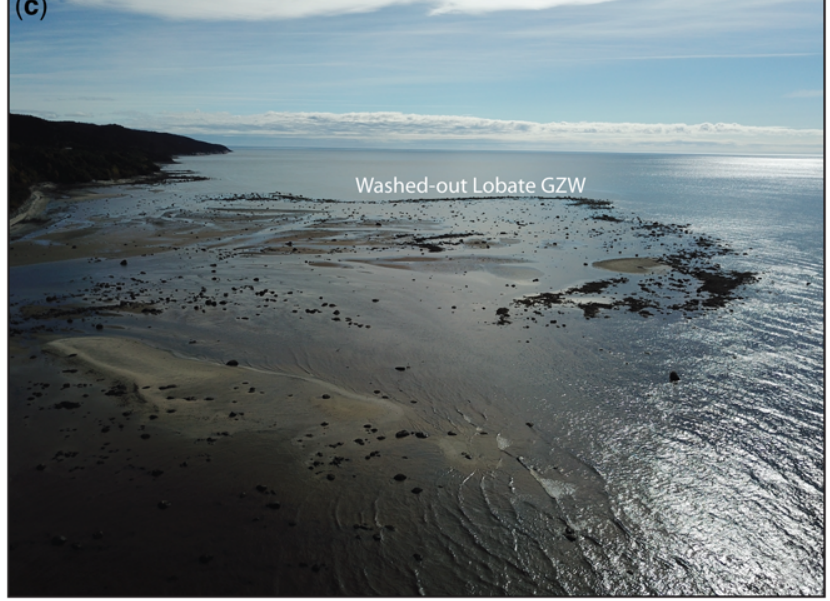

Fig. 12. Air photographs taken from a drone of washed-out moraines and GZWs outcropping at low tide along the modern coastline between Baie-des-Anglais (BA) and Pointe-des-Monts (PDM). These lag deposits now form boulders barricades and were first reported by Bernatchez (2003). These deposits are possibly associated with GZ3, although no GZW or moraines have been observed in deeper waters (i.e. down-ice). 
(a)

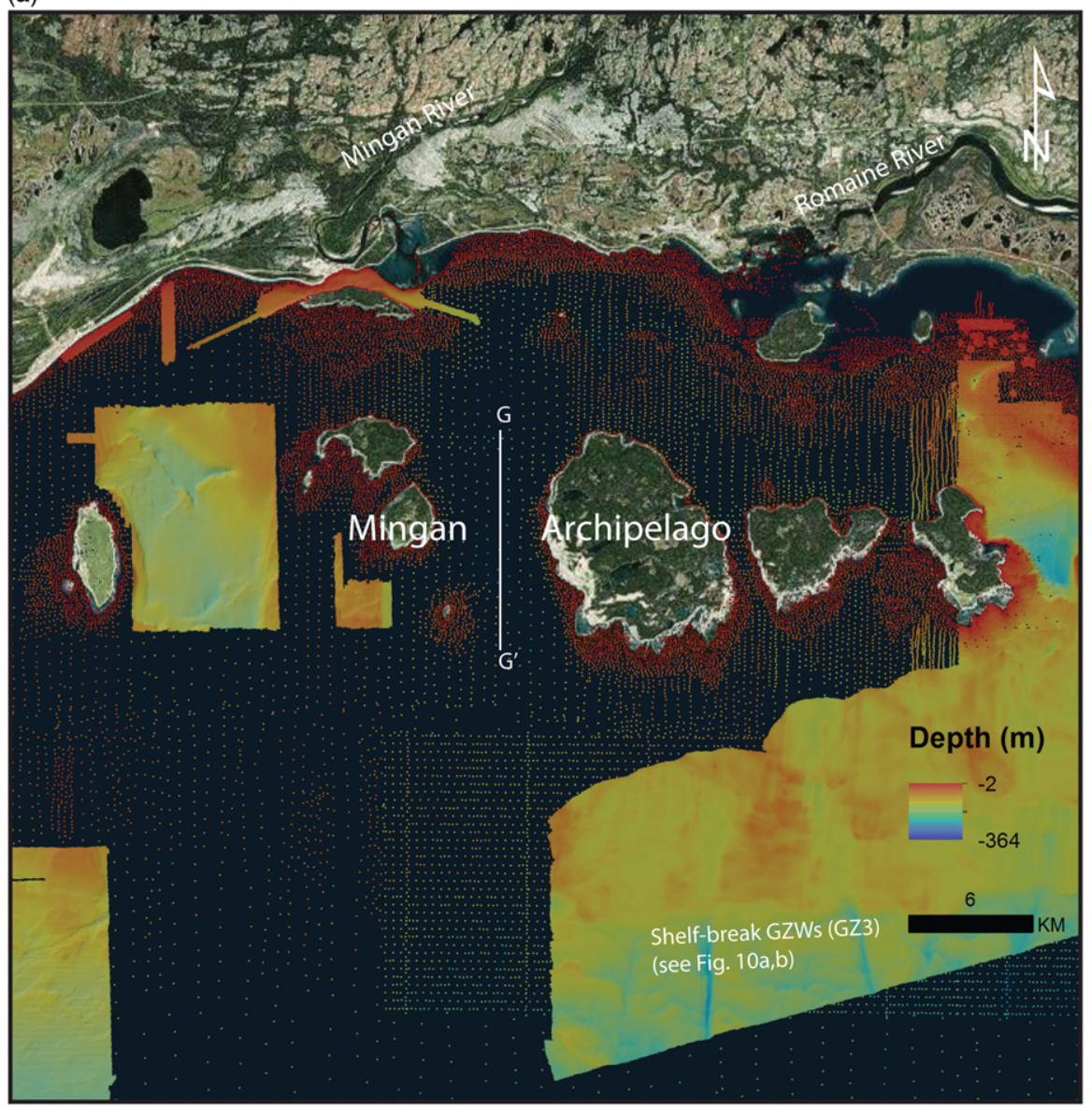

(b)

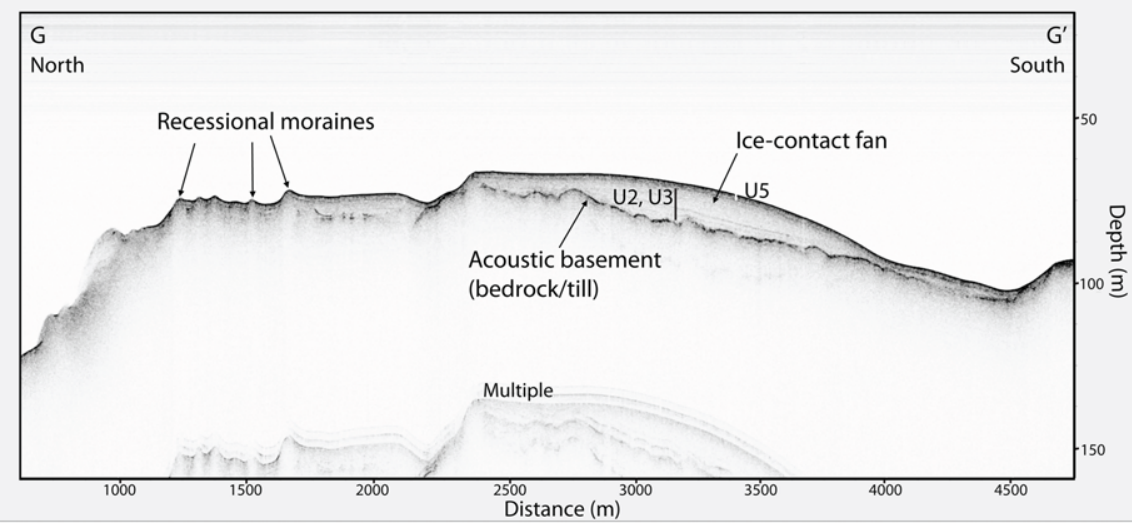

Fig. 13. Location (a) of a Chirp sub-bottom profile (b; location $\mathrm{G}-\mathrm{G}^{\prime}$ ) showing an ice-contact fan between two islands of the Mingan Archipelago. A series of retreat moraines observed up-ice was constructed as the ice margin retreated to the north after stabilizing to deposit this fan. The fan contains a sequence of glaciomarine (U3) and postglacial sediments (U5). Depth based on TWTT at $1500 \mathrm{~m} \mathrm{~s}^{-1}$. This fan is associated with a local grounding zone system constructed after GZ3. 


\section{P. LAJEUNESSE ET $A L$.}

GZ2 system (Figs 4 \& 5). In the Mingan Archipelago $\mathrm{a}<12 \mathrm{~m}$-thick bulge-shape fan is constructed above a cuesta ridge at 65-90 m water depths (Fig. 13b) north of a shelf-break GZW associated with GZ3. A series of frontal moraines are observed up-ice (i.e. to the north) of this fan. This fan could represent a fourth local stage of temporary stabilization of the ice margin.

\section{Mega-scale glacial lineations}

Three assemblages of MSGLs are observed in relation with GZs in the study area: MSGL1, north (up-ice) of the GZ1 system; MSGL2, on the shelf north (up-ice) of the shelf-break GZ2 system; and MSGL3, up-ice of GZ3 systems (Figs 4, 6, 7a, 9a $\&$ 10a). These MSGL systems consist of streamlined lineations oriented towards the deep waters of the gulf, i.e. to the SE and south, depending on their location. Off the Lake Walker valley axis, the surface of lobate GZWs associated with the GZ2 system show 600-3000 m-long MSGLs (MSGL2) (Fig. 3). MSGLs are also present up-ice in association with the lobate GZW (GZ2 system: MSGL2) of the southern Sept-Îles Archipelago (Figs 4 \& 5). In this sector, some of the MSGLs are curved owing to the confinement of the ice flow in the inter-island channel. MSGLs terminating at the shelf break and at the upper limit of the GZ2 system (Figs 4, 9 \& 10) located south and east of Sept-Îles indicate rapid ice velocities during this grounding and stabilization episode. MSGL3 also appear up-ice of GZ3 systems in the Baie-des-Anglais (Fig. 7a) and Mingan sectors (Fig. 10a).

\section{Implications}

Three GZ systems mapped at c. 180 (GZW1), c. 120 (GZW2) and c. $80 \mathrm{~m}$ (GZW3) $\pm 20 \mathrm{~m}$ water depths off the Québec North Shore have been revealed in great detail by swath bathymetry data combined with archived and recently acquired high-resolution seismic profiles. GZWs, together with the laterally connected morainal banks and subaqueous icecontact fan deposits, record three phases of episodic retreat (Dowdeswell et al. 2008) of the LIS margin as it migrated northwards and grounded in the shallower sectors off the Québec North Shore. Localized sets of De Geer moraines observed in shallower area near the coast suggest a more gradual and slow retreat (Dowdeswell et al. 2008), at least following the stabilization stage associated with the deposition of the GZ system located offshore. According to the deglaciation model of Atlantic Canada (Shaw et al. 2006), the observed GZWs and ice-contact fans were constructed after $14.8 \mathrm{ka} \mathrm{BP}$ as the marinebased margin of the LIS stabilized and re-advanced locally following its rapid retreat across the Gulf of St Lawrence owing to active iceberg calving. The landform disposition along three distinct isobaths demonstrates that bathymetry played a major role in controlling stabilities of the ice margin by reducing iceberg calving rates in lower relative water depths and by bringing the ice margin further away from the buoyancy threshold, allowing it to ground and stabilize. Bathymetry related to the shelf morphology influenced the geometry of these GZWs, forming curvilinear and lobate GZWs on gentle and regular slopes and shelf-break GZWs along major bedrock scarps. Lobate GZWs were specifically constructed on gentle slopes influenced by constrained ice flow in front of structural terrestrial valleys.

The mapping of submarine glacial landforms in the study area allows the identification of three major stages of grounding and stabilization of the LIS margin during its general south-to-north retreat:

(1) A first stage (Stage 1: GZ1) at c. $180 \mathrm{~m} \pm 20 \mathrm{~m}$ water depths traced by the observation of curvilinear GZWs between the Pentecôte and Ste Marguerite river mouths, where swath bathymetry imagery is available at greater depths.

(2) A second stage (Stage 2: GZ2) observed at c. $120 \mathrm{~m} \pm 20 \mathrm{~m}$ between the Pentecôte and Romaine river mouths, by the mapping of curvilinear, shelf-break and lobate GZWs, morainal banks and ice-contact fans. The available swath bathymetry data between $c .90$ and c. $150 \mathrm{~m}$ water depths over an extensive sector along the Québec North Shore allows us to trace this grounded ice margin over a distance of $>300 \mathrm{~km}$. After leaving its first stable position at greater depths, the LIS margin stabilized along the $120 \mathrm{~m}$ isobath $( \pm 20 \mathrm{~m})$, which is marked along most of the mapped region by a major break in slope. This ice-margin stillstand was coeval with rapid ice flows that allowed the delivery of subglacial sediments to the grounding zone, as indicated by the high density of MSGLs distributed immediately up-ice (NW to NE) of these GZWs. The subaqueous ice-contact fan observed above the Manowin-Petite-Basque GZ system was constructed after the ice margin retreated from the shelf break and stabilized on the northern slopes of the trench.

(3) A third stage of ice margin stabilization (GZ3) occurred near the modern coastline at depths of $c .60$ to $c .80 \mathrm{~m}$ and deposited curvilinear GZWs and ice-contacts fans. From the analysis of the swath bathymetry imagery and seismic data, this ice margin position can only be traced locally owing to: (a) the deep burial of GZWs and ice-contact deposits under large deltas that prograded during and after 


\section{LATE WISCONSINAN GROUNDING ZONES OF THE LAURENTIDE ICE SHEET MARGIN}

deglaciation when RSL fell; and (b) the continuity of these deposits in shallower unsurveyed sectors or on-land, where they form washed-out boulder ridges and deposits in some coastal sectors. Available data indicate that a GZ with a restricted ice shelf was still present offshore the Pentecôte and Walker valleys axis. This stage predates the $>500 \mathrm{~km}$-long terrestrial Québec North Shore moraine that is estimated to have been deposited mostly inland near the end of the Younger Dryas episode BP (Dubois \& Dionne 1985; Dietrich et al. 2018).

\section{Conclusions}

High-resolution swath bathymetry imagery and acoustic sub-bottom profiler data combined with airgun seismic data allowed a reconstruction of the major stages of deglaciation of the NW Gulf of St Lawrence from the detailed mapping of GZWs, ice-contact subaqueous fans, moraines and MSGLs. The preliminary analysis of these datasets leads to the following conclusions:

- GZWs observed along the shelf of the NW Gulf of St Lawrence record a phase of episodic retreat of the Laurentide Ice Sheet margin following its rapid retreat in the deeper waters of the Laurentian Channel.

- Deglaciation of the NW Gulf of St Lawrence occurred in three major stages of grounding and stabilization of the Laurentide Ice Sheet margin during which three distinct series of GZ deposits, consisting mostly GZWs but also moraines and fans, were constructed along the same isobaths: Stage 1, GZ1, $180 \pm 20$ m; Stage 2, GZ2, $120 \pm$ $20 \mathrm{~m}$; Stage 3, GZ3, $80 \pm 20 \mathrm{~m}$. This pattern indicates that bathymetry exerted a strong control on stabilization stages of the LIS margin during its northward retreat.

- The geometry of GZWs depended on shelf and coastal morphology, with curvilinear GZWs constructed on gentle and regular slopes, shelfbreak GZWs along major escarpments and lobate GZWs down-ice from confined inter-island basins and off the mouth of major glacial valleys.

- The first stage of stabilization of the LIS margin (Stage 1, GZ1 system) extended in the deep waters off the northwestern Gulf of St Lawrence.

- Stage 2 (GZ2 system) extended parallel to the modern Québec North Shore coastline. GZWs, moraines and subaqueous ice-contact fans associated with of this stage are observed continuously over a distance of $>200 \mathrm{~km}$ on the swath bathymetry imagery.

- Stage 3 (GZ3 system) extended only in places on the Québec North Shore shelf. In the western sector of the study area, a large portion of this system indeed coincides today with the coastline forming washed-out lobate GZWs and moraines and even lies inland.

- Eskers and other glacial meltwaters morphologies are not present on the Québec North Shore shelf, despite the extensive high-resolution swath bathymetry coverage in the area.

Swath bathymetry data are needed west and south of the study area in order to trace the extent of the Stage 1 and Stage 2 GZ systems and to map MSGLs associated with the St Lawrence Ice Stream and its tributaries. Radiocarbon-dated material collected in sediment cores through glaciomarine deposits of the region should also provide more timing constraints on these stages of ice margin stability during deglaciation and their links to Late Wisconsinan climatic events. LiDAR data over the Québec North Shore region should allow connection of the reported submarine grounding-zone depositional systems to terrestrial moraines, especially those associated with the Late Wisconsinan and large-scale St Narcisse and Québec North Shore moraine systems.

Acknowledgements This project was funded by a Natural Science and Engineering Research Council of Canada Discovery grant to P.L. and ship-time grants to P.L., Guillaume St-Onge (UQAR) and Jacques Locat (U. Laval). The multibeam bathymetry data was gratefully provided by the Canadian Hydrographic Service office in Mont-Joli, QC. We thank Alexandre Normandeau (GSC) for his assistance during fieldwork. We also thank Sarah Greenwood, an anonymous reviewer and Daniel Le Heron, the associate editor of this volume, who provided comments that helped improve the quality of the manuscript. This work is a contribution to the 'SeqStrat-Ice' ANR project 12-BS06-14.

\section{References}

Batchelor, C.L. \& Dowdeswell, J.A. 2015. Ice-sheet grounding-zone wedges (GZWs) on high-latitude continental margins. Marine Geology, 63, 65-92.

Bernatchez, P. 2003. Évolution Littorale Holocène et Actuelle des Complexes Deltaïques de Betsiamites et de Manicouagan-Outardes: Synthèse, Processus, Causes et Perspectives. PhD thesis, Université Laval.

Bernatchez, P. \& Dubois, J.-M.M. 2004. Bilan des connaissances de la dynamique de l'érosion des côtes du Québec maritime laurentien. Géographie physique et Quaternaire, 58, 45-71.

Boulton, G.S. \& ClaRK, C.D. 1990. A highly mobile Laurentide ice sheet revealed by satellite images of glacial lineations. Nature, 346, 813.

Brennand, T.A. 2000. Deglacial meltwater drainage and glaciodynamics: inferences from Laurentide eskers, Canada. Geomorphology, 32, 263-293.

Clark, C.D., KNIGHT, J.K. \& GRAy, J.T. 2000. Geomorphological reconstruction of the Labrador Sector of the Laurentide Ice Sheet. Quaternary Science Reviews, 19, 1343-1366. 


\section{P. LAJEUNESSE ET $A L$.}

Courtney, R.C. 2013. Canada GEESE 2: Visualization of Integrated Marine Geoscience Data for Canadian and Proximal Waters. Geoscience Canada, 40, 141-148.

Dietrich, P., Ghienne, J.-F., Normandeau, A. \& LajeuNESSE, P. 2016. Upslope-migrating bedforms in a proglacial sandur delta: cyclic steps from river-derived underflows? Journal of Sedimentary Research, 86, 113-123.

Dietrich, P., Ghienne, J.F., Normandeau, A. \& Lajeunesse, P. 2017. Reconstructing ice-margin retreat using delta morphostratigraphy. Scientific Reports, 7, 16936.

Dietrich, P., Ghienne, J.-F., Lajeunesse, P., Deschamps, R., Normandeau, A. \& Razin, P. 2018. Deglacial sequences and glacio-isostatic adjustment: Quaternary compared with Ordovician glaciations. In: LE HERON, D.P., Hogan, K.A., Phillips, E.R., Huuse, M., Busfield, M.E. \& Graham, A.G.C. (eds) Glaciated Margins: The Sedimentary and Geophysical Archive. Geological Society, London, Special Publication, 475, https:// doi.org/10.1144/SP475.9

Dowdeswell, J.A. \& Fugelli, E.M.G. 2012. The seismic architecture and geometry of grounding-zone wedges formed at the marine margins of past ice sheets. Geological Society of America Bulletin, 124, 1750-1761.

Dowdeswell, J.A., Canals, M., Jakobsson, M., Todd, B.J., Dowdeswell, E.K. \& Hogan, K.A. (eds) 2016a. Atlas of Submarine Glacial Landforms: Modern, Quaternary and Ancient. Geological Society, London, Memoirs, 46.

Dowdeswell, J.A., Canals, M., Jakobsson, M., TodD, B.J., Dowdeswell, E.K. \& Hogan, K.A. 2016b. The variety and distribution of submarine glacial landforms and implications for ice-sheet reconstruction. In: DowDESwell, J.A., Canals, M., Jakobsson, M., Todd, B.J., Dowdeswell, E.K. \& Hogan, K.A. (eds) Atlas of Submarine Glacial Landforms: Modern, Quaternary and Ancient. Geological Society, London, Memoirs, 46, 519-552, https://doi.org/10.1144/M46.183

Dowdeswell, J.A., OtTeson, D., Evans, J., Ó Cofaigh, C. \& ANDERson, J.B. 2008. Submarine glacial landforms and rates of ice-stream collapse. Geology, 36, 819-822.

DREDGE, L.A. 1983. Surficial geology of the Sept-Iles area, Quebec North Shore. Geological Survey of Canada Memoir, 408, 40.

Dubois, J.M. \& Dionne, J.C. 1985. The Québec North Shore moraine system: a major feature of Late Wisconsin déglaciation. In: Borns, H.W., JR, LASAlle, P. \& Thompson, W.B. (eds) Late Pleistocene History of Northeastern New England and Adjacent Quebec. Geological Society of America, Special Papers, 197, 125-133.

Duchesne, M.J., Pinet, N., Bédard, K., St-Onge, G., LajeuNesse, P., Campbell, D.C. \& Bolduc, A. 2010. Role of the bedrock topography in the Quaternary filling of a giant estuarine basin: the Lower St. Lawrence Estuary, Eastern Canada. Basin Research, 22, 933-951.

Dyke, A.S. 2004. An outline of North American deglaciation with emphasis on central and northern Canada. In: Ehlers, J. \& GibBard, P.L. (eds) Developments in Quaternary Sciences, Elsevier, 2, 373-424.

Fulton, R.F. 1995. Surficial materials of Canada, Geological Survey of Canada, Map 1880A, scale 1:5000 000.

Hein, F.J., Syvitski, J.P.M., Dredge, L.A. \& Long, B.F. 1993. Quaternary sedimentation and marine placers along the North Shore, Gulf of St-Lawrence. Canadian Journal of Earth Sciences, 30, 553-574.

Josenhans, H. \& Lehman, S. 1999. Late glacial stratigraphy and history of the Gulf of St. Lawrence, Canada. Canadian Journal of Earth Sciences, 36, 1327-1344.

Klassen, R.A., Paradis, S., Bolduc, A.M. \& Thompson, R.D. 1992. Glacial landforms and deposits, Labrador, Newfoundland and eastern Québec. Geological Survey of Canada, Map 1814A, 1:1 000000 scale.

LAJEunESSE, P. 2014. Buried preglacial fluvial gorges and valleys preserved through Quaternary glaciations beneath the eastern Laurentide Ice Sheet. Geological Society of America Bulletin, 126, 447-458.

LaJeunesse, P. 2016. Late-Wisconsinan grounding-zone wedges, northwestern Gulf of St. Lawrence (eastern Canada). In: Dowdeswell, J.A., Canals, M., Jakobsson, M., Todd, B.J., Dowdeswell, E.K. \& Hogan, K.A. (eds) Atlas of Submarine Glacial Landforms: Modern, Quaternary and Ancient. Geological Society, London, Memoirs, 46, 227-228, https://doi.org/10. 1144/M46.91

Lajeunesse, P. \& Allard, M. 2002. Sedimentology of an ice-contact glaciomarine fan complex, Nastapoka Hills, eastern Hudson Bay, northern Québec. Sedimentary Geology, 152, 201-220.

Lajeunesse, P. \& St-Onge, G. 2013. Late-Wisconsinan submarine moraines along the north shore of the Estuary and Gulf of St. Lawrence (Eastern Canada). In EGU General Assembly Conference Abstracts, Vol. 15.

Lajeunesse, P., Locat, J., St-Onge, G. \& Labbé, G. 2007. Morphosedimentology of submarine mass-movements and gravity flows offshore Sept-Îles, NW Gulf of St. Lawrence (Québec, Canada). In: Lykousis, V., SaKellariou, D. \& Locat, J. (eds) Submarine Mass Movements and Their Consequences. Advances in Natural and Technological Hazards Research. Springer, Dordrecht, 27, 287-296.

Lajeunesse, P., St-Onge, G., Locat, J., Duchesne, M.J., Higgins, M.D., Sanfaçon, R. \& Ortiz, J. 2013. The Corossol structure: A possible impact crater on the seafloor of the northwestern Gulf of St. Lawrence, eastern Canada. Meteoritics and Planetary Science, 48, 2542-2558.

LøNNE, I. 1995. Sedimentary facies and depositional architecture of ice-contact glaciomarine systems. Sedimentary Geology, 98, 13-43.

Loring, D.H. \& NotA, D.J.G. 1973. Morphology and sediments of the Gulf of St. Lawrence. Fisheries and Marine Services, 182, 147 p.

Margold, M., Stokes, C.R. \& Clark, C.D. 2015. Ice streams in the Laurentide Ice Sheet: Identification, characteristics and comparison to modern ice sheets. EarthScience Reviews, 143, 117-146.

Mosola, A.B. \& Anderson, J.B. 2006. Expansion and rapid retreat of the West Antarctic Ice Sheet in eastern Ross Sea: possible consequence of over-extended ice streams? Quaternary Science Reviews, 25, 2177-2196.

Normandeau, A., Lajeunesse, P. \& St-Onge, G. 2013. Shallow-water longshore drift-fed submarine fan deposition (Moisie River Delta, Eastern Canada). GeoMarine Letters, 33, 391-403.

Normandeau, A., Dietrich, P., Lajeunesse, P., St-Onge, G., Ghienne, J.-F., Duchesne, M. \& Francus, P. 2017. Timing and controls on the delivery of coarse sediment 


\section{LATE WISCONSINAN GROUNDING ZONES OF THE LAURENTIDE ICE SHEET MARGIN}

to deltas and submarine fans on a formerly glaciated coast and shelf. Geological Society of America Bulletin 129, 1424-1441.

OcchietTI, S. 2007. The Saint-Narcisse morainic complex and early Younger Dryas events on the southeastern margin of the Laurentide Ice Sheet. Géographie physique et Quaternaire, 61, 89-117.

Occhietti, S., Govare, E., Klassen, R., Parent, M. \& VinCENT, J.-S. 2004. Late Wisconsinian-Early Holocene deglaciation of Québec-Labrador. In: EHLERS, J. \& GIBBARD, P.L. (eds) Quaternary Glaciations - Extent and Chronology, Part II. Elsevier, Amsterdam, 243-273.

Occhietti, S., Parent, M., Lajeunesse, P., Robert, F. \& Govare, É. 2011. Late Pleistocene-Early Holocene Decay of the Laurentide Ice Sheet in Québec-Labrador. In: Ehlers, J. \& GibBard, P.L. (eds) Developments in Quaternary Sciences. Elsevier, Amsterdam, 15, 601-630.

Peltier, W.R., Argus, D.F. \& Drummond, R. 2015. Space geodesy constrains ice age terminal deglaciation: The global ICE-6G_C (VM5a) model. Journal of Geophysical Research: Solid Earth, 120, 450-487.

PiPer, D.J.W., Shaw, J. \& Skene, K.I. 2007. Stratigraphic and sedimentological evidence for late Wisconsinan sub-glacial outburst floods to Laurentian Fan. Palaeogeography, Palaeoclimatology, Palaeoecology, 246, 101-119.

Poiré, A.G., Lajeunesse, P., Normandeau, A., Francus, P., St-Onge, G. \& Nzekwe, O.P. 2018. Late-Quaternary glacial to postglacial sedimentation in three adjacent fjord-lakes of the Québec North Shore (eastern Canadian Shield). Quaternary Science Reviews, 186, 91-110.

Powell, R.D. \& Alley, R.B. 1997. Grounding-line systems: processes, glaciological inferences and the stratigraphic record. Geology and Seismic Stratigraphy of the Antarctic Margin, 2, 169-187.

Shaw, J., Gareau, P. \& Courtney, R.C. 2002. Palaeogeography of Atlantic Canada 13-0 kyr. Quaternary Science Reviews, 21, 1861-1878.
Shaw, J., PIPER, D.J.W. ET AL. 2006. A conceptual model of the deglaciation of Atlantic Canada. Quaternary Science Reviews, 25, 2059-2081.

Stokes, C.R., TARASOv, L. ET AL. 2015. On the reconstruction of palaeo-ice sheets: recent advances and future challenges. Quaternary Science Reviews, 125 , $15-49$.

St-Onge, G., Lajeunesse, P., Duchesne, M.J. \& Gagné, H. 2008. Identification and dating of a key Late Pleistocene stratigraphic unit in the St. Lawrence Estuary and Gulf (Eastern Canada). Quaternary Science Reviews, 27, 2390-2400.

Storrar, R.D., Stokes, C.R. \& Evans, D.J.A. 2014. Increased channelization of subglacial drainage during deglaciation of the laurentide ice sheet. Geology, $\mathbf{4 2}$, 239-242.

SYviTSKI, J.P.M. 1991. Towards an understanding of sediment deposition on glaciated continental shelves. Continental Shelf Research, 11, 897-937.

Syvitski, J.P. 1993. Glaciomarine environments in Canada: an overview. Canadian Journal of Earth Sciences, 30, 354-371.

Syvitski, J.P.M. \& PRAEG, D.B. 1989. Quaternary sedimentation in the St. Lawrence Estuary and Adjoining Areas, Eastern Canada: an overview based on high-resolution seismo-stratigraphy. Géographie physique et Quaternaire, 43, 291.

Tarasov, L., Dyke, A.S., Neal, R.M. \& Peltier, W.R. 2012. A data-calibrated distribution of deglacial chronologies for the North American ice complex from glaciological modeling. Earth and Planetary Science Letters, 315-316, 30-40.

TodD, B.J. 2016. The Laurentian Channel: a major crossshelf trough in Atlantic Canada. In: Dowdeswell, J.A., Canals, M., Jakobsson, M., Todd, B.J., Dowdeswell, E.K. \& Hogan, K.A. (eds) Atlas of Submarine Glacial Landforms: Modern, Quaternary and Ancient. Geological Society, London, Memoirs, 46, 161-162, https://doi.org/10.1144/M46.124 